$\frac{37}{2-2}-19$

$24 D_{\text {savom }}$

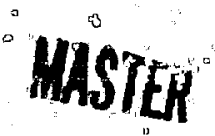

(1)

SImulated Nuclear Optical Slgnatures Uoing Explosive Light Sources (kLS)*

.
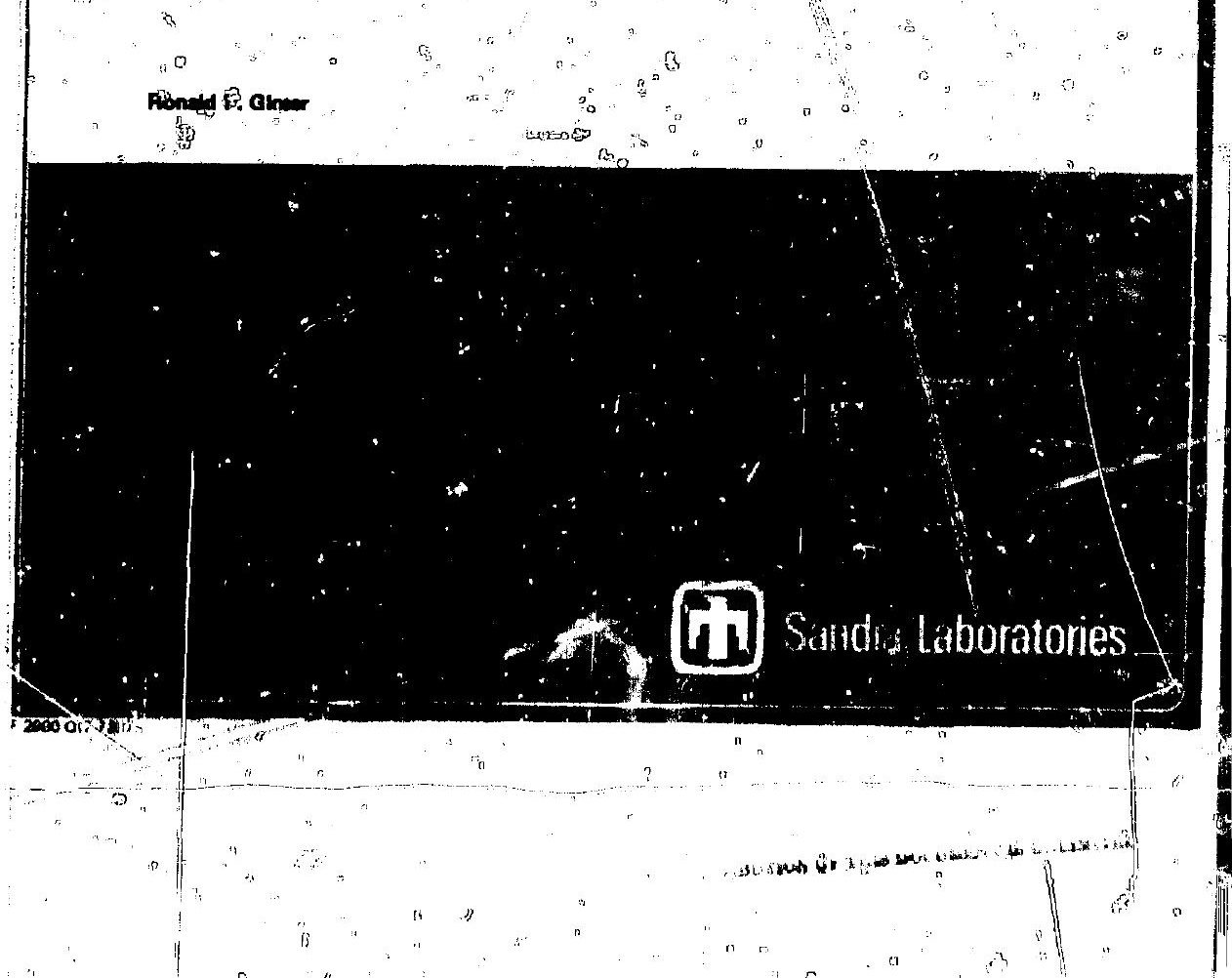
SAND78-0925

Unildrilted Releane

Printed May 1078

\section{SIMULATED NUCLEAR OPTICAL SIGNATUAES USING \\ EXPLOSIVE LIGHT SOURCES (ELS)*}

Fonald F. Glaser

Speclal Projecte Divislon 1245

Sandia Laboratories

Albuquerque, NM B7185

1

ABSTRACT

Four Explealve LIght Source (ELS) testa were conducted, Gimulating a nuclear optlcal wave shape. Visual observation was achicved at $25 \mathrm{~km}$. line-af-alght bhangmeter detectlon at $10.5 \mathrm{~km}$, and scattered-light deteation at $t \mathrm{~km}$. The Liss would be a valuable trairing aid for Army troups.

Funding for the Nuclear Burat letectlon System (NBUS) development and for partletpition

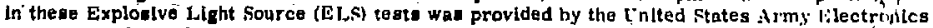
Fewearch and Development Command [TSAERAlXCOM. Fort Monmouth, Sis under Project Number 76-08008. 


\section{ACKNDWLEDGMENT}

The author thanka John Diahon of Sclente Appllcationa, Inc and Major J/m Mayo of the Defense Nuclear Agency for supplying the Explosive Light Sources; Terry Leighley, Clarence Robertson and Gene Moore of Sandia Laboratories for their photography; and Gary Laabs and his crew for Ground Zero Bupport. 


\section{Summary}

Introduction

Exploalve Llotht Source

Firat Pulae Unit

Siecond Puilue Unit

Timine

Photo Detector' Syatem.

Supor sultcane Optical

Old Style Sultcare

Nucleas Eurat Dethetion System

Date

Shot 1

Shot 2

Shot 3

Shot 4

Conclivitione

Optcal Tranamieston

Direct va Scattered Ratio and Shape

Nuclear Optical Simulator

Firet Pulae Rate of Riso

Second Pulse Shape

Souree Symmitry

Output and Yleld Scaling

\section{ILLUSTAATIONS}

\section{Flere}

1

2

3

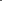

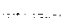

Nuclear Burat Opkical TIme Htotory (Wideband SIIlcon Detectpr)

Exploniva Light fource Physical setup

10

Exploelve Lunt Source; 04-pt First Pulae Syatem Bofore Inflatinf With Oxy pin 


\section{ILLUSTRATIONS (cont)}

Fifure

8

7

8

8

10

11

12

13

14

15
Broadband sllicon Reaponso

Tower-Mounted NBDS Sensor Station

KIrtland East (Sandia A rea)

Coyote Test Fleld

8-Bag ELS

Shot 1

Shot 2

Shot 3

Shot 4

Plot of Irradiance at Firet Maximum
Page

13

14

16

17

18

21

23

26

29

33

\section{TABLES}

\section{Tableg}

I

Bhangmeter Characteristics

12

II

Weather Conditions

15

Shot $1(2 / 28 / 78)$

20

Shot $2(3 / 2 / 7 \theta)$

23

Shot $3(3 / 3 / 78)$

25

Shot $4(3 / 7 / 7 \theta)$

28

Dlrect Scattered Ratio

34

NBDS Microprocessor DiscrLm Inants

35

36

37

37

38 
Data gathered from ELS teats has indlcated that:

- Clear alr. line-of-elght optical transmission at ranges of from 0.3 to $10.6 \mathrm{~km}$ follows a $1 / \mathrm{R}^{2}$ dependance, allowing the ELS to be treated as a point source.

- From the large baga of the second pulee unit, Hght output scales as the number of bags to the two-thirds power, each bag yielding approximately 7 E7 Watts output.

- The proper timing of firing between the small and large bags permits simulation of a nulcear optical waveshape.

- The rise time of light from the first pulse is slower than that of a nuclear explosion, thereby limiting the range of detectability. When using NBDS gensors, their range is 14 mited to $1 \mathrm{~km}$ while that of the direct line-of-sight bhangmetere (SSO, OSS) is $10.5 \mathrm{~km}$.

- The ELS could be a valuable training aid for Arrny troops to emplace an NBDS aystem. 


\title{
SIMULATED NUCLEAR OPTICAL SIGNATURES USING \\ EXPLOSLVE LIGHT SOURCES (ELS)
}

\author{
Introduction
}

Four Explostve Light Source (ELS) teste were conducted on the test range at Sandia Laburatorles in Albuquerque (SLA) from 28 February through 7 March 1978. The Appendix lists the participants and the flelded experiments. Although geveral types of measuring devices were used. this report documents only the optical time histories measured hy the bhangmeters and the NBDS, and explains the conclusions reached. In general, the Lour shots made it posslble to gather clearElr optical transmission data, determine the sultability of ELS to simulate the optical effects of a nuclear burst, and provide experience for the larger scale ELS tests to be conducted at Fort Ord, CA in Aprll.

\section{Explosive Light Source}

The ELS is a mixture of aluminum powder and oxygen which, when detonated, produces extremely intense light and can be used to produce an optical time history that resembles a nuclear explosion (Figure 1). It also causes a large pulse of thermal radiation bul little accompanying air blast. The ELS was developed and fielded by John Dishon of Science Applications Inc (SAI) under contract to the Defene Nuclear Agency (DNA). "It has been called "the world's largest flashbulb" because it uses the same general princlple as an ordinary flashbulb. i. $c$. , an envelope filled with oxygen in whlch alumlnum is explosively burned (Flgure 2). The intense light is produced in two pulses, each pulse generated with a different unit.

\section{First Pulse Linit}

The first pulge of maximum hrlllance in each shot was produced hy an explosive system (E-system) consiating of 16 unita, each containing four points. A point consisted of a detonutor. a 6- to 8-in.piece of primer cord and a 2-g packet of sluminum powder cneasing the end of the primer cord. The polnts were supported on PVC piping inside an envelupe made of polyethelene bags $10 \mathrm{ft}$ tall and $2 \mathrm{ft}$ in diameter (Figure 3). The bags were inflated with oxygen just before detonation. All 64 polnte detonated almost gimultaneously. 


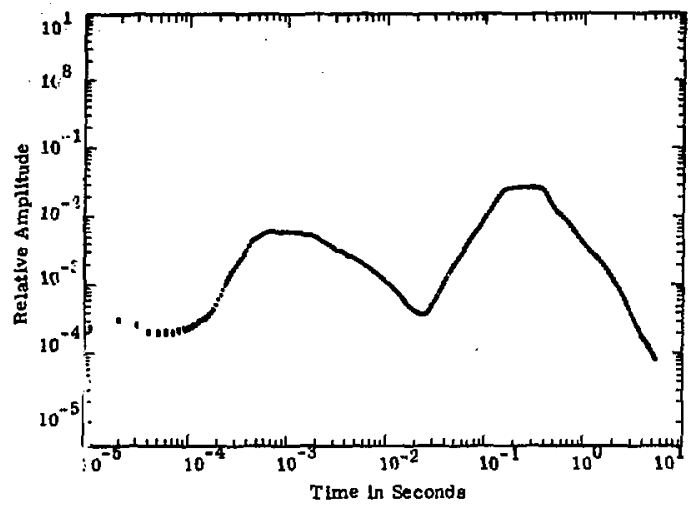

Flgure 1

Nuclear Buret Optical Time History (WIdeband sllicon Detector)

Figure 2

Explosive Light Source Physical Setup
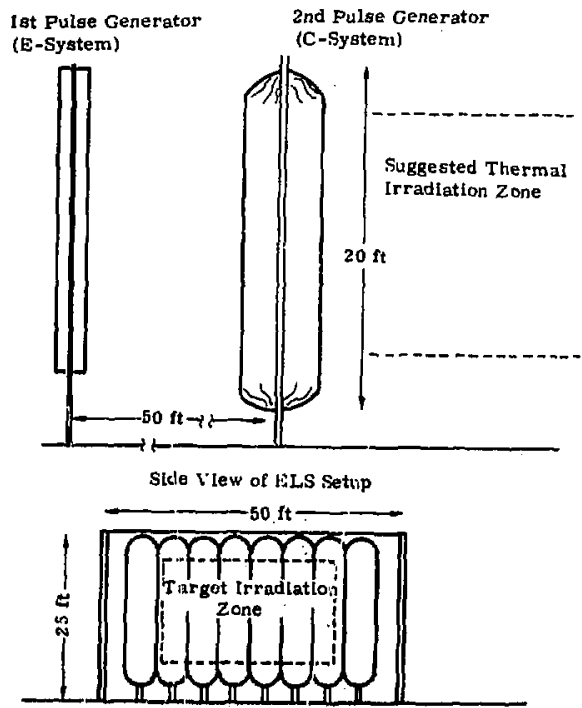

Qack V lew of DLsi Satup 


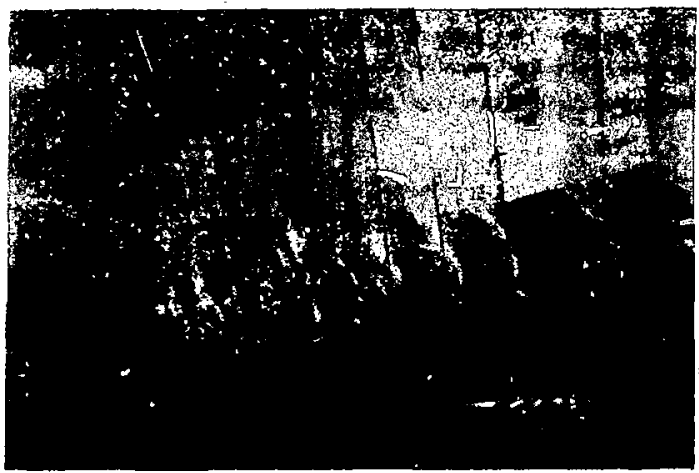

Eigure 3. Explosive Light Source; 64-pt Firgt Pulse Syotem Before Inflating With Oxygen

\section{Socond Pulse Unit}

The second pulse of maximum brillance in each shot was produced by a cannon system (C-ayatem) conslating of elght bags or unita. Each unlt was composed of a polyethelene bag. 20 ft tall and 2 ft in dlameter, fllled with oxygen and containing a flare-type ignition device positioned approximately $3 \mathrm{ft}$ from the bottom. Uaing pressurized aitrogen as the fluld, a fluidizing dovlce at the base of each bag injected approxlmately $5 \mathrm{~kg}$ of aluralnum powder past the flare which lgnited it (Figure 4).

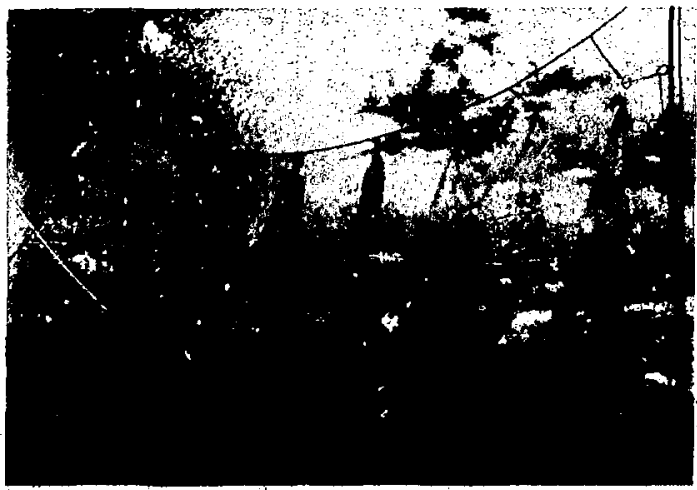

Flgure, 4. Explonive Light Source; 8-Bag Second Pulue Bystem Before Innating with Oxygen 
Proper tlming of aluminum injection and Nere Ignition in the second pulse unit in relation to the detonation of the frot pulee agstern was mandatory to produce a almulated nuclear optical olgnature. Within limits, tlming between unita could ke varied to simulate different nuclear ylelds.

\section{Photo Detector Syriems}

Table I Ilots the photo detector systems (bhangrauters) used to mensure the light and summarizes thels characterigtics. Brlefly. there were two types of bhangmetera: unidirectional line-orsight and omnidirectional scattered-Hght detectors (a:leo called nuclear-burst detection bystem (NBDS) вengor stations). The former, of various vinteges, different sensitivity, different eampledume bases, etc, had to be almed toward the source. The latter sensor is independent of azimi $h$ and has a field-of-Vlew (FOV that is elavated above the horizon (source) to detect scattered IIght.

\section{TABLE I}

Bhangmeter Characterlatics

\begin{tabular}{|c|c|c|c|c|c|}
\hline Intrument & FOV & $\begin{array}{l}\text { Trlger } \\
{\left[W / \mathrm{cm}^{2}\right]}\end{array}$ & $\begin{array}{l}\text { Trlgger Rate } \\
\left(\mathrm{W} / \mathrm{cm}^{2}-\mathrm{s}\right) \\
\end{array}$ & $\begin{array}{l}\text { Senditulty } \\
\left(W / \mathrm{cm}^{2}-\mathrm{V}\right) \\
\end{array}$ & $\begin{array}{l}\text { Saturation } \\
\left(\mathrm{CV} / \mathrm{cm}^{2}\right)\end{array}$ \\
\hline $\begin{array}{l}\text { Super Sulteane, Optical } \\
\text { SSO A001 (LR) } \\
\text { SSO A(\%02 (LR) }\end{array}$ & 5* Radlua virect & 4 E-8 & 3. $1 \mathrm{E}-4$ & $2 \mathrm{E}-4$ & 3. $1 E-4$ \\
\hline \multicolumn{6}{|l|}{$\begin{array}{l}\text { Old stylo Soltense } \\
\text { (Fornter YSRM) }\end{array}$} \\
\hline $\begin{array}{l}\operatorname{Oss} 2 \\
\text { OSS } 3\end{array}$ & 12* Semletrcle Direct & $7,75 \mathrm{E}-9$ & $3 E-2$ & $1 E-4$ & $2.5 \theta E-4$ \\
\hline \multicolumn{6}{|l|}{$\begin{array}{l}\text { Nuriter Bur nt Detection } \\
\text { Syntem Senvor Station }\end{array}$} \\
\hline $\left.\begin{array}{l}\text { NBDS A001 } \\
\text { NBDS A002 } \\
\text { NBDS } A 003\end{array}\right\}$ & $\begin{array}{l}+40+20.50 \\
360^{\circ} \text { Axmisth } \\
\text { Scettored }\end{array}$ & $6.26 \mathrm{E}-7$ & $1.3 E-2$ & $2 E-2$ & $1.85 \mathrm{E}-1$ \\
\hline
\end{tabular}

\section{Super Sultcre Opticyl}

The Super Sultcane Optlical (SSO) (Flgure 5) ie an Instrument that can meagure the opticul output a a function of time of light-producing phenomena. The sjatem uses an unflitered silicon photodlode aenuor and difital amplerd with varibble time resolution, Figure it a graph showing a typical broadband sllicon detector xesponse ae a function of vavelength. The digital output leivels are logarithmically spaced over alx decadei and the 200 digltal ampling timei are paeudologarith .

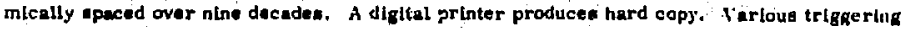
options can be relected with a switch and tic gain of the optical detector may be increased by a fector of 140 for lone range (LR) capabilitiea. 


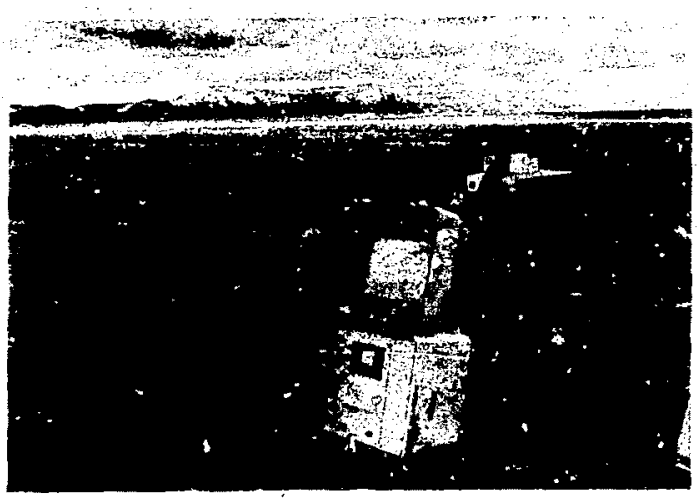

Figure 5. Super Suitcage Optical

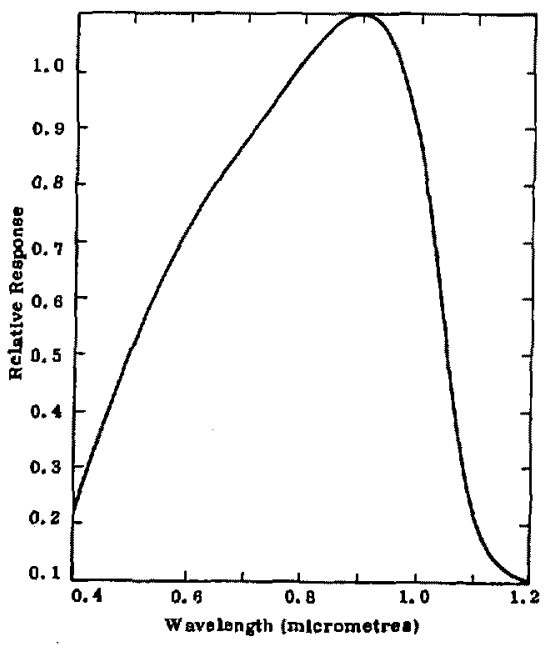

Figure 6, Erokdband sllteon Reaponge 
Besiden the digltal record, $16-\mathrm{mm}$ color movle can be made with a camerh mounted on the detectir angembly. The EOV of the camere in clonely matched and aligned with the optice sf the detectir to record the event alignment and weather conditions. Two SSOs were ured for the ELS tests. 2

\section{Old Style Sultcée}

The Old Style Sultcaze (OSS) is an Inetrument thit measures the optical fime hlatory of IIghtproducing phenomena. The syotem ures an unflitered ellicon photodiode gensor and digital samples Whth variable time reaolution. The 112 digital-output levels are logerithmically apaced over abx decades; the 24 linearly upaced preamples and the 136 preudo-logarlthmically apaced maln lamples cover elx decades, A digital printer provldea hard copy autput. Three OSSs were used during the FLs terta.

\section{Nuclear Burai Detectlon Syatem}

The Nuclenr Burst Detection System (NBDS) is normally an array of gensor stations (Figure 7) that detect and report charecteristice of nuclear bursts, such as time of burst, yleld, and ground interaction. To accomplith this, each sensor station uses a microprocessor to analyze the nuclear optical time history and the coincident arrival of an electromagnetic pulse (EMP) aignal. Since the ELS does not produce an EMP, these requiremente were bypageed with hard wiring. Each station obtains optical data using an unflitered silicon photodfode sensor and digital samples with variable time resolution. The 250 difital-output levels are logarthmically spaced over six decades, and the 448 digital sampling times are pseudologarithmically apaced over 5-1/2 decades. In all casea but one on the first shot, the Bensor stations were reprogrammed to function as independent instrumente that measure the opticul time hlstory of any Ligh-producing phenomena that meets threshold ind rate-of-rise criteria. When programmed in this manner, each sensor station interfaces with a Silent 700 terminal that provide hard copy digital output. Three sensor guallong were used during the ELS teate.

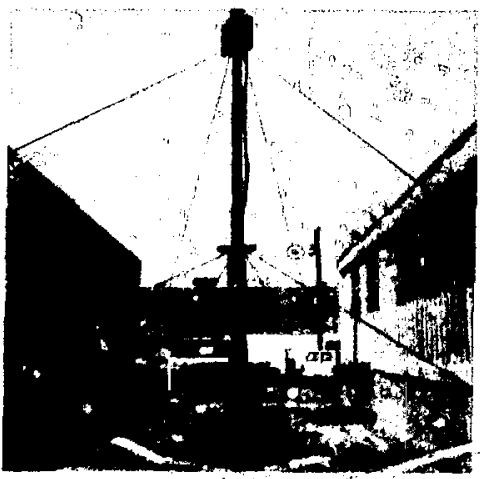

\section{Flgure 7}

Tower-Mounted NBDS Sensor Station 
The bhangmeter data are organized by shot; Figures 8 and 8 are maps that show the locations of the detectors; Table II Hots weather conditlons reported at the Albuquerque alrport; and Figure 10 (four parts) is a requence of still photographs of an ELS shot. For size reference, the cameraprotection shed shown in the foreground and to the left in Figure 10 was constructed of $4 \times 8-1$ plywood and asbestos sheets.

TABLE II

Weather Condtions

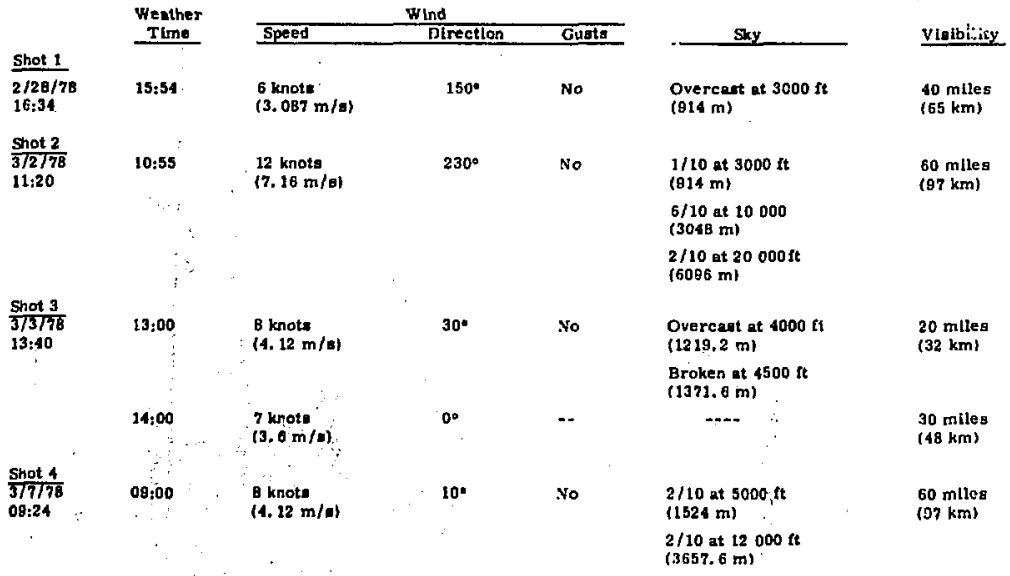




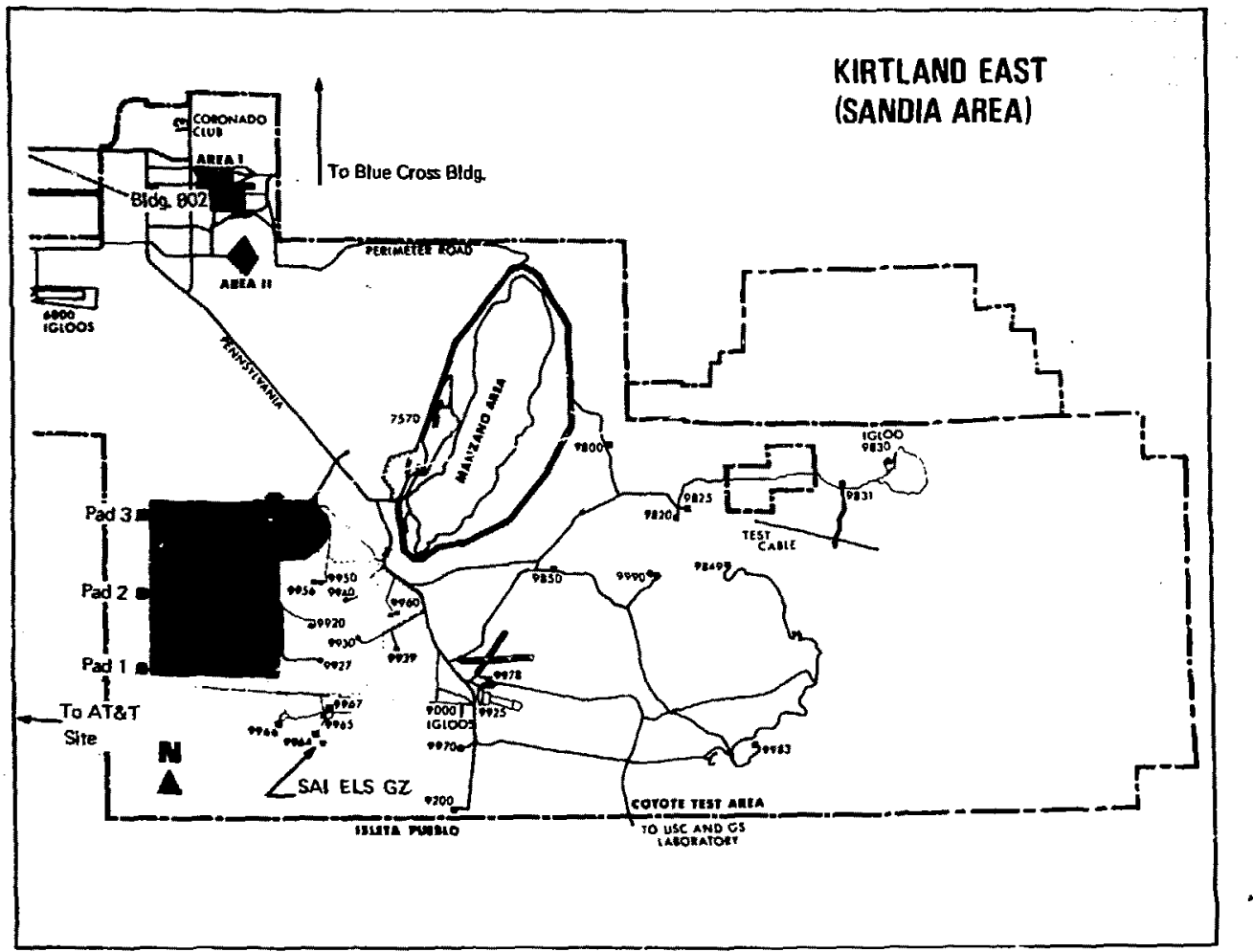

Figure 8. Kirtland East (Sandla Area) 


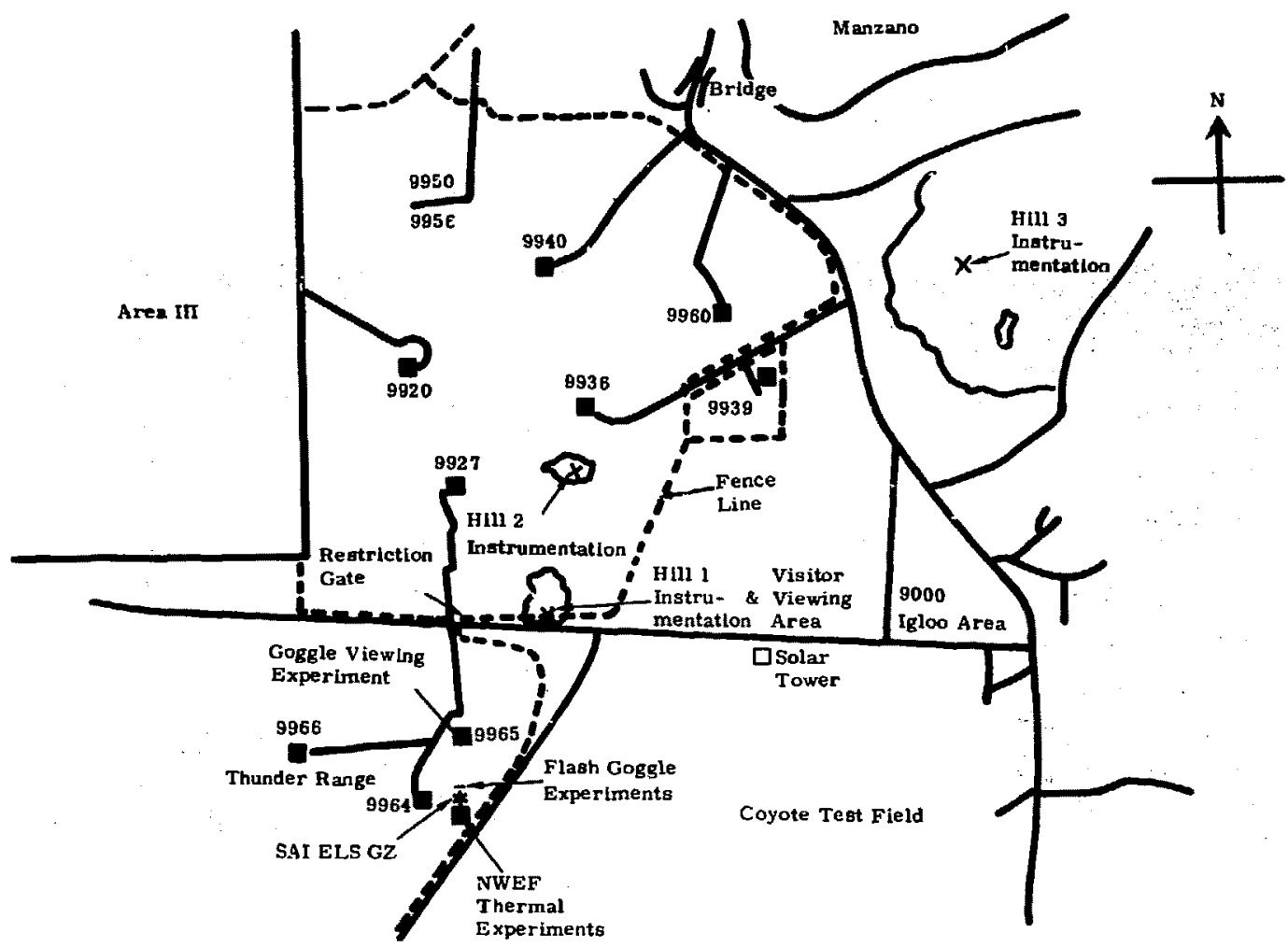




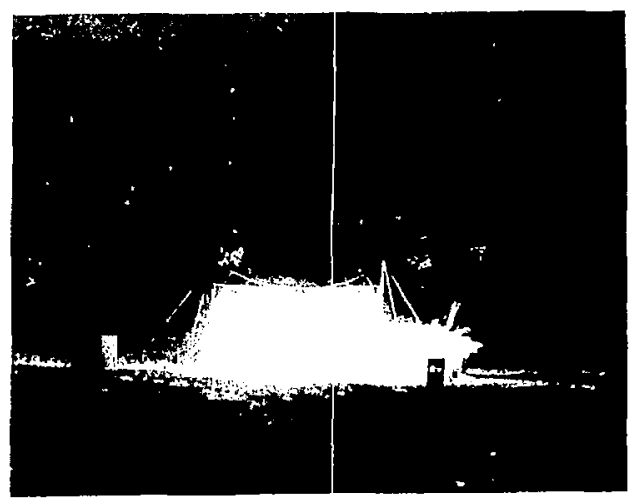

(a)

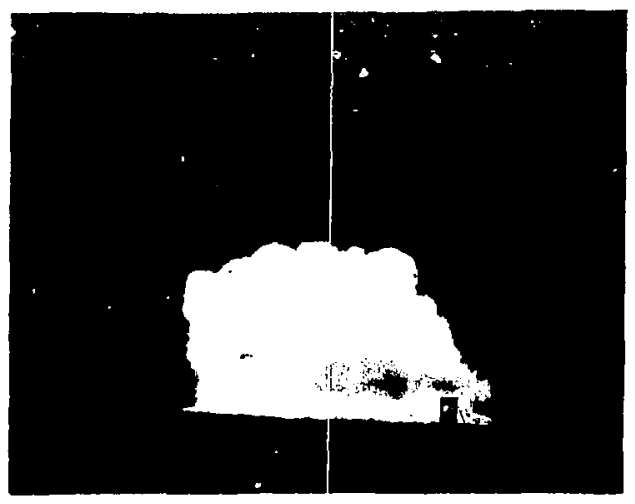

(b)

Fıgure 10, 8-Bag ELS 


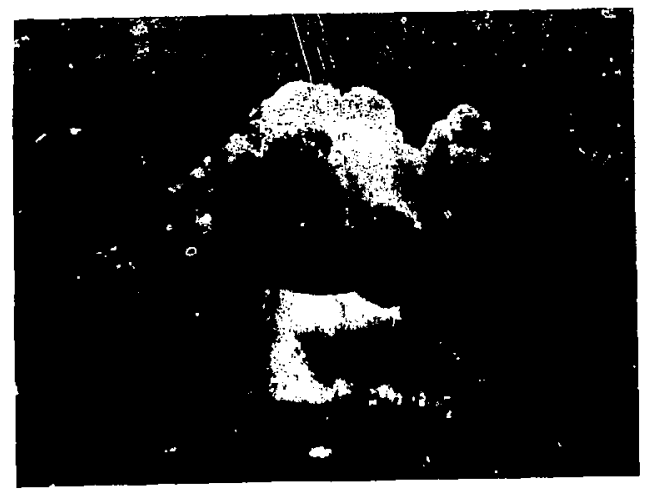

(c)

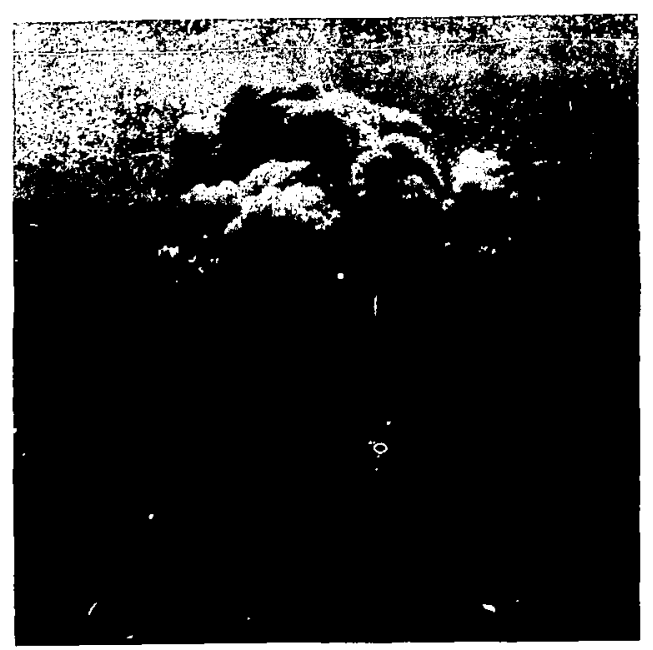

(d)

Figure 10. (concluded) 
Table tII summarizes bhangmeter data obtained from Shot 1. Optical ttre hlatories from four line-of-gight detectars at rangee from 1.0 to $10.5 \mathrm{~km}$ are plotted in Figure 11 . This ELS produced optical power of 1.6E8 W-silleon from the first pulse and 2, 1 EB W-ailicon from the second. It triggered and pakeed all digcrimlnante of an unmodifled (EMP requlrement excepted) NBDS gensor station at $1 \mathrm{~km}$.

\section{TABLE חI:}

Shot $1(2 / 28 / 78)$

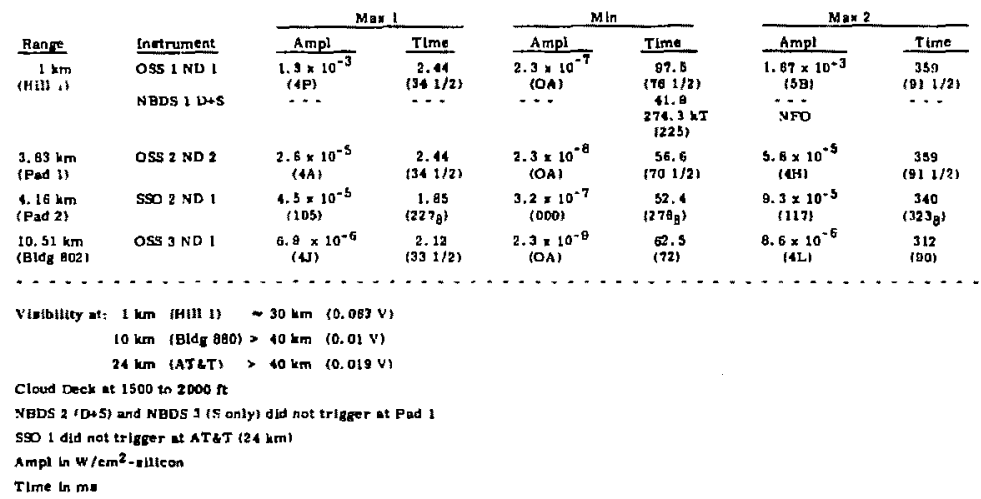




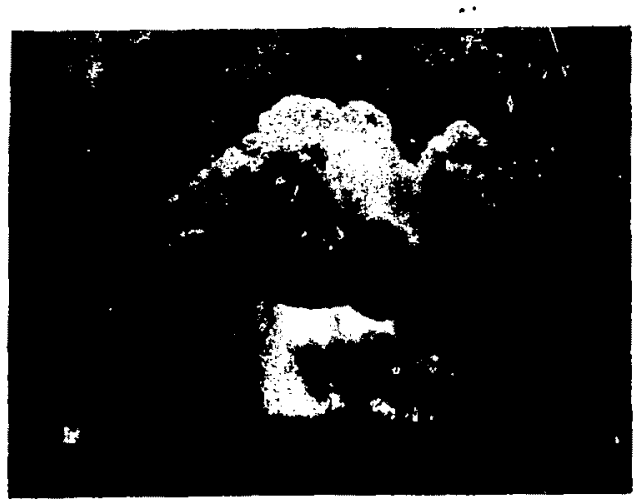

(c)

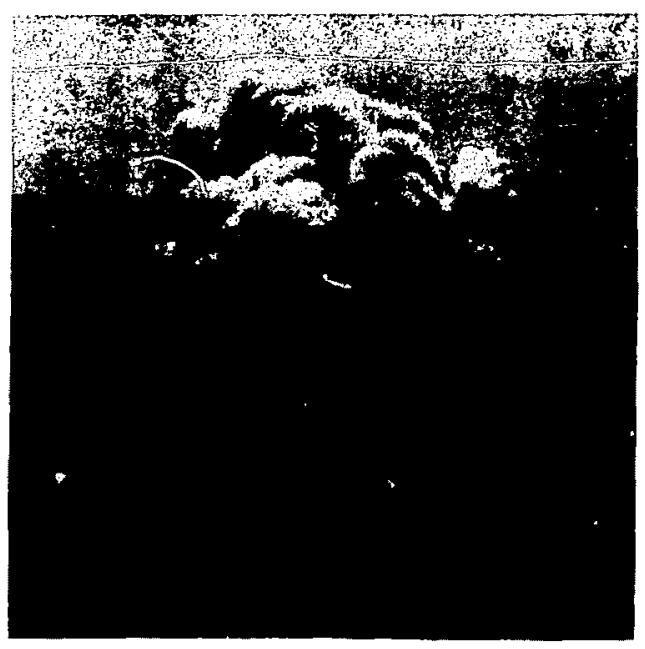

(d)

Figure 10. (concluded) 


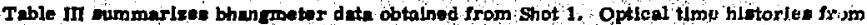

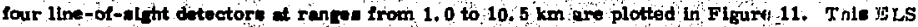

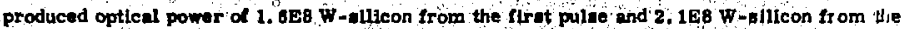
wecond. It trl cored and pened al dincriminente of en uninodifled (EMP requlremon's extepted) NBDS nentor etrán it $1 \mathrm{~km}$.

\section{TAPIF IT}

Shot 1 (2/28/78)

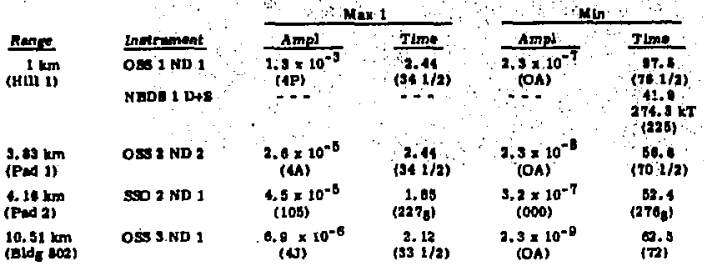

\begin{tabular}{|c|c|}
\hline Ampl & Tlm \\
\hline $\begin{array}{l}1.67 \times 10^{-3} \\
(5 B) \\
=-5 \\
\text { N.0 }\end{array}$ & $\begin{array}{c}359 \\
\operatorname{tg1} 1 / 21 \\
-=-\end{array}$ \\
\hline $0_{(4)}=10^{-5}$ & $\begin{array}{l}380 \\
\text { (9) } 1 / 2)\end{array}$ \\
\hline $\begin{array}{c}0.3 \times 10^{-5} \\
(117)\end{array}$ & $\begin{array}{c}940 \\
\left(93_{8}\right)\end{array}$ \\
\hline $\begin{array}{l}\text { 0. } 4 \times 10^{-6} \\
(4 L)\end{array}$ & $\begin{array}{r}912 \\
(90)\end{array}$ \\
\hline
\end{tabular}

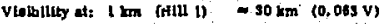

$10 \mathrm{~km}$ (ald (ais) > $40 \mathrm{~km}(0,01 \mathrm{~V}), \ldots$

$24 \mathrm{~km} \mathrm{ATtr)}>10 \mathrm{hm}$ (0,0sev).

Cloud Dock at isop io a00 $\mathrm{h}$

NADS 2 (Des) and knDS I (s only) dus net triscer it Pad 1

S50 I did not triers at ATeT .24 km)

A mopl in $\mathrm{W} / \mathrm{cm}^{2}$-illicon

Timi in me 


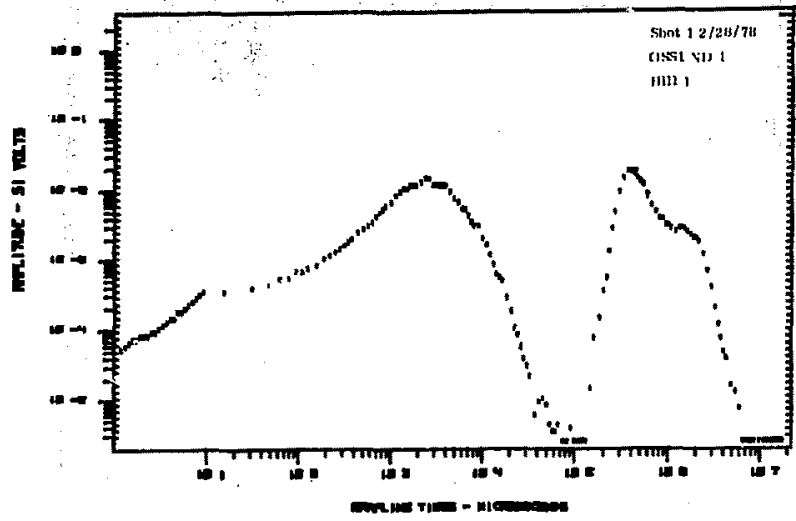

(a)

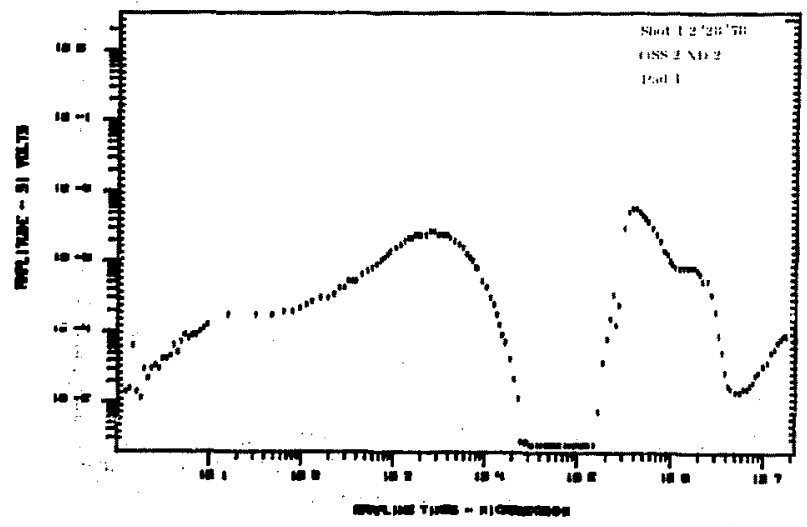

(b)

Figure 11, Shot 1 


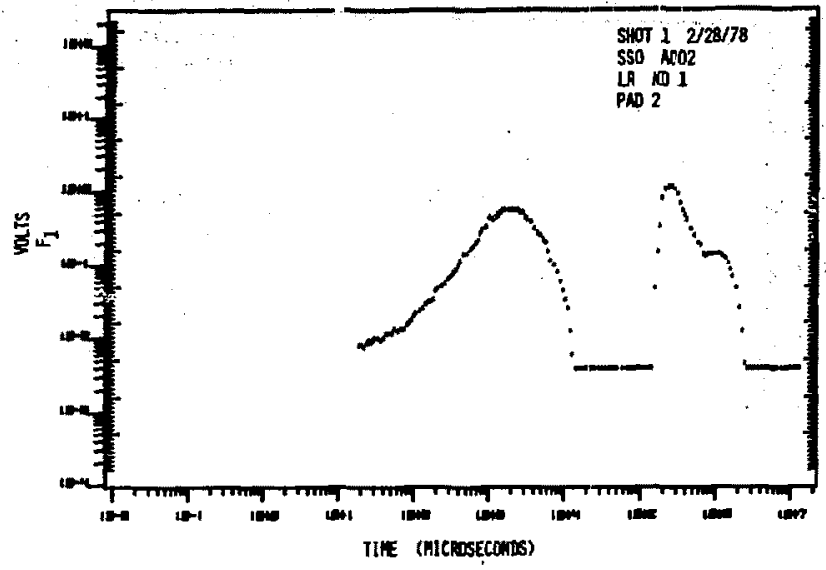

(c)

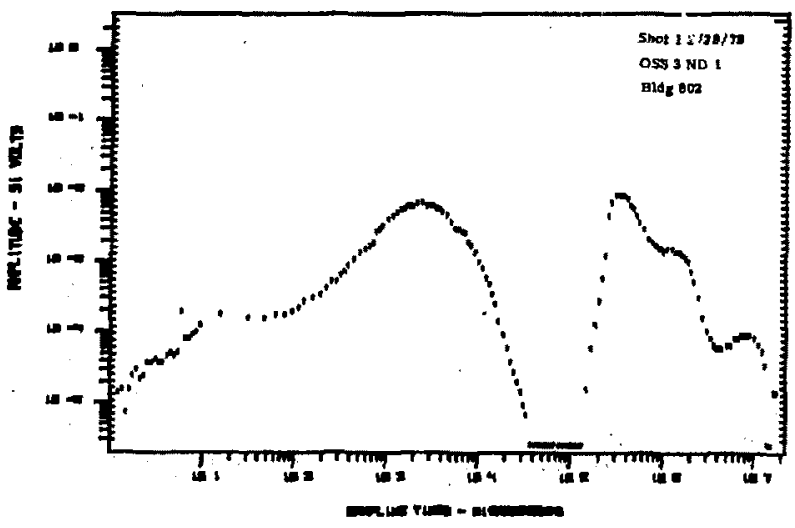

(d)

Figure 11, (concluded) 
Bhangmeter data for Shot 2 is nummarleed in Table IV. Optical the hlatorles trom three Ihe-of-s Light detectors at ranges from 1.0 to $3.6 \mathrm{~km}$ are plotted in Flgure 12, This ELS produced optlcal powar of $8.7 E 7 \mathrm{~W}-$ ablicon trom the firat pulse and 1.2F7 W-glicon trom the aecond. The low output and Irregular ohape of the second pulese was caused by improper ignition on all tte bags.

\section{TABLE TV}

Shat $2(3 / 2 / 78)$

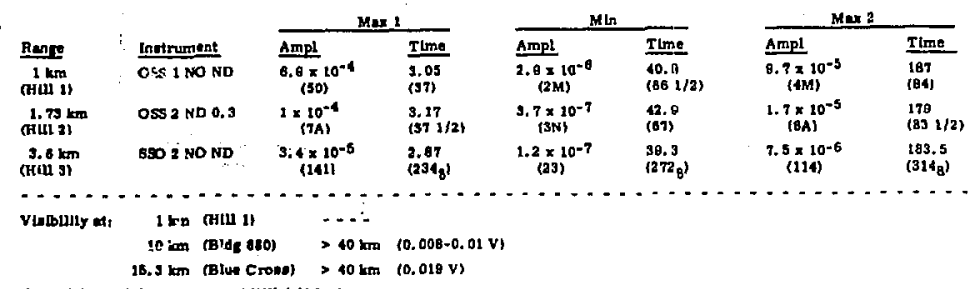

NBDS 1 (D+S) did not triterer at Hil 1 (1 km]

NBDS a (D+S) and NBDS 3 (S only) dld not triger at Hill 2

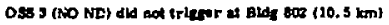

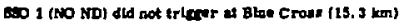

hmpi in $7 / \mathrm{em}^{2}-$ ableon

The hime

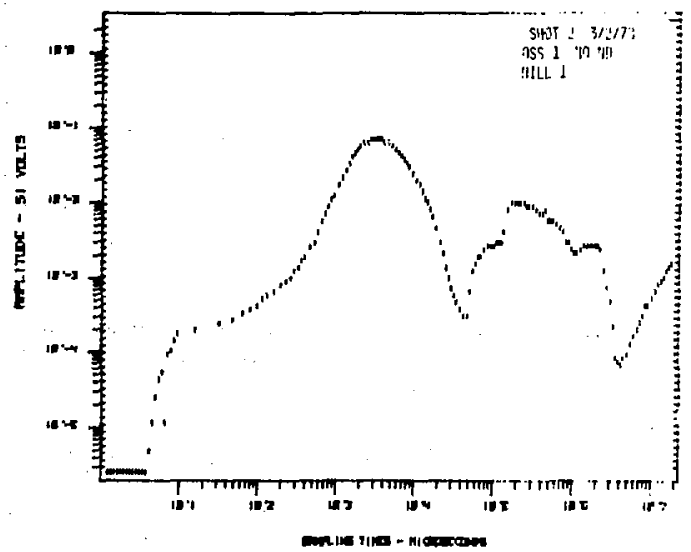

(a)

Figure 12. Shot 2 


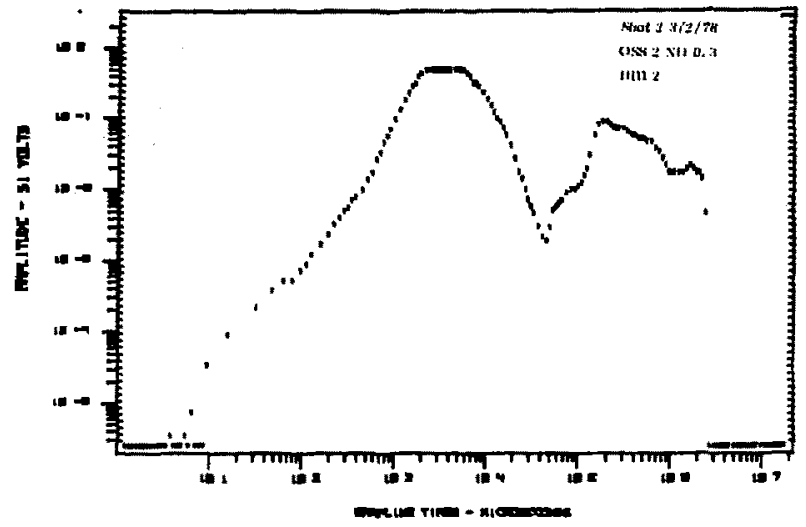

(b)

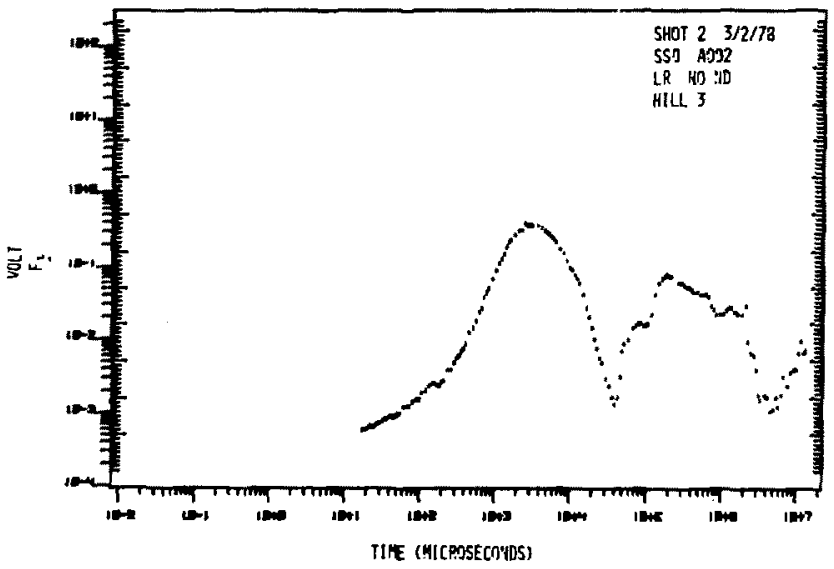

(c)

Figuro 12, (concluded) 
Bhengmeter dati for shot 3 in eummarized in Table $v$ and optical time hlotories from four lne-of-elight detector at range from 1.0 to $3.6 \mathrm{~km}$ are ploted in Figuro 13. Thta ELS pro-

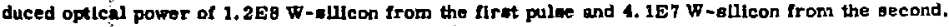
The low output and irregular, tro-hump shape of the second pulse was caused by the use of aluminum powder partscles of two diferent eizes which burned at different rates. This shot triggered detectors airth, cout $b$ and enet of the cource and provided information on drectionaleffects.

\section{TAELE V}

Shot $3(9 / 9 / 79)$

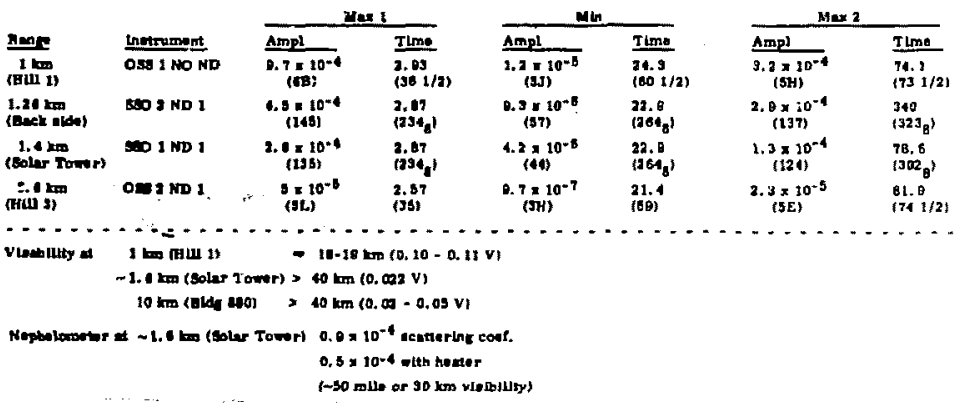

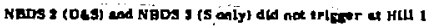

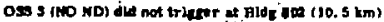

NeDs 1 we nat tloked.

Ampi in $w / \mathrm{cm}^{3}$ - suteon

Time in ane. 


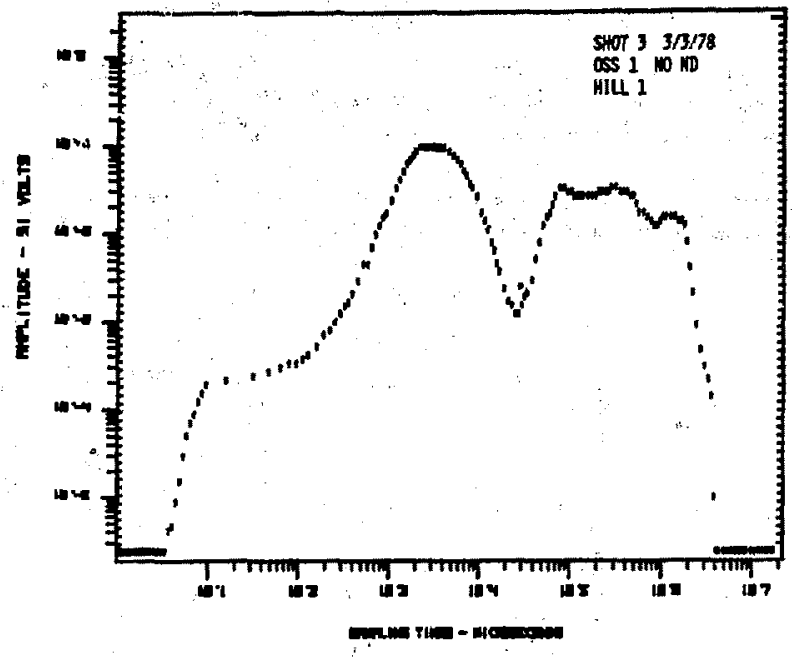

(a)

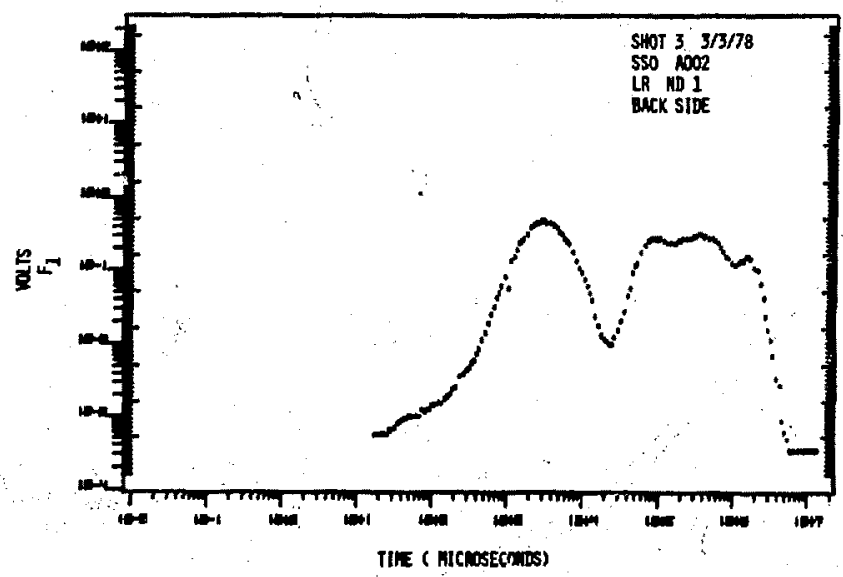

o:

(b)

Figure 13, Shot 3 


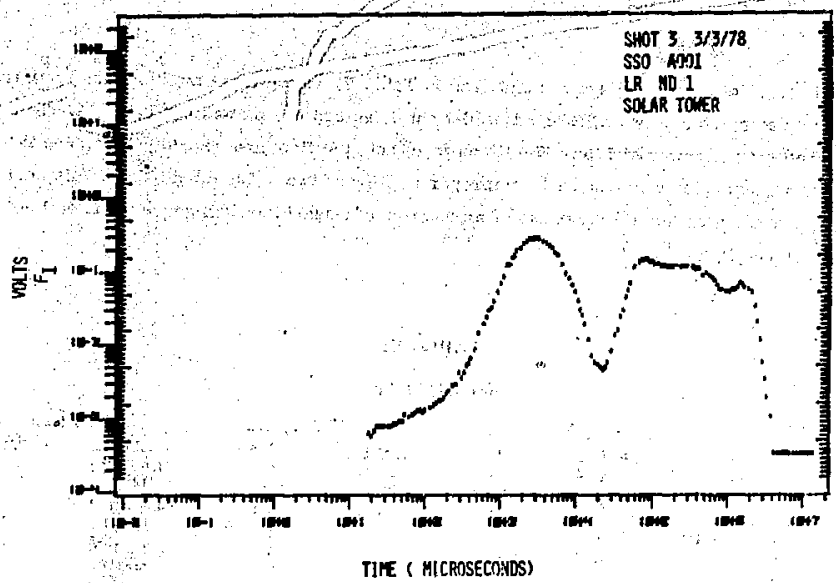

(c)

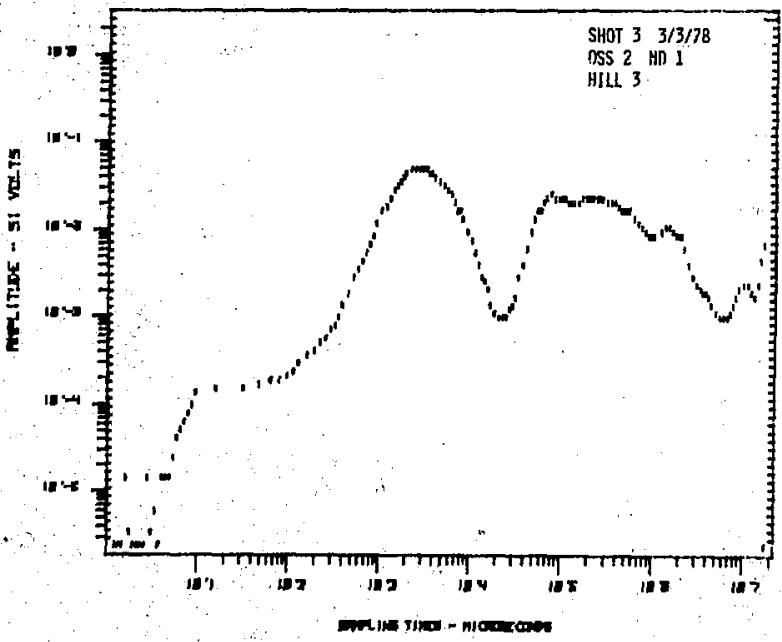

(d)

Figure 13, (concluded) 


\section{Shot 4}

Bhangmeter data for Shot is nummarlzed in Table VL and optlcal time hiatorles from five line-of-ight detectors and two NBDS scattered-1labt detectord are plotted in Figure 14. Thin ELS produced optical power of $1.5 \mathrm{~EB}$ w-milcon from both the flret and eecond pulae. The lrregular shepe of the eecond pulee was caused by improper Ignttion of two of the efight bags, Thlo ahot provided infornation on the effectlvenese of attenuation of flath-blindneat goggles ard on line-ofsight vs scattered light.

\section{TABLE YI}

Shot $4(3 / 7 / 78)$

\begin{tabular}{|c|c|c|c|c|c|}
\hline \multirow{3}{*}{$\frac{\text { Ranct }}{-300 \mathrm{~m}}$} & \multirow{3}{*}{$\frac{\text { Initrument }}{\text { Oss I ND t. }}$} & \multicolumn{2}{|c|}{$\operatorname{Max} 1$} & \multicolumn{2}{|c|}{$\mathrm{Min}$} \\
\hline & & Ampl & TIme & Ampl & $\tau_{\text {Lms }}$ \\
\hline & & $\begin{array}{c}1.1 \times 10^{-2} \\
1142 g^{1}\end{array}$ & $\begin{array}{l}2.83 \\
(3 \in 21 / 2)\end{array}$ & $2.1 \times 10^{-3}$ & 37 \\
\hline & $\begin{array}{l}\text { Oge } 2 \text { ND } 2 \\
\text { Panutue Corgle }\end{array}$ & $\begin{array}{c}1.5 \times 10^{-3} \\
\left(145_{8}\right)\end{array}$ & $\begin{array}{l}2.87 \\
(35)\end{array}$ & $\because 1_{(32,)^{2}}^{2.3 \times 10^{-6}}$ & $\begin{array}{l}39.1 \\
6611 / 2\end{array}$ \\
\hline & $\begin{array}{l}\text { OSS } 3 \text { NO ND } \\
\text { "Dark Cogthle" }\end{array}$ & $\begin{array}{c}B .2 \times 10^{-5} \\
\left(162_{B}\right)\end{array}$ & $\begin{array}{l}2,81 \\
(9 B)\end{array}$ & $\begin{array}{l}1.1 \times 10^{-7} \\
\left.170_{g}\right)^{-7}\end{array}$ & $\begin{array}{l}3 ! \\
\text { (65) }\end{array}$ \\
\hline $\begin{array}{l}1 \mathrm{~km} \\
\text { (Hiil } 1)\end{array}$ & $38 \times 1$ ND 1 & $\begin{array}{c}1.2 \times 10^{-3} \\
(162)\end{array}$ & $\begin{array}{l}2.87 \\
\left(234_{8}\right)\end{array}$ & $\begin{array}{l}2.8 \times 10^{-6} \\
(38)\end{array}$ & $\begin{array}{l}96 \\
\left(27 i_{8}\right)\end{array}$ \\
\hline & $\begin{array}{l}\text { NBDS } 2 \\
\text { Rinte }+10\end{array}$ & $\begin{array}{l}1.2 \times 10^{-5} \\
(79)\end{array}$ & $\begin{array}{l}2.00 \\
(03)\end{array}$ & $\begin{array}{c}8.6 \times 10^{-8} \\
(00)\end{array}$ & $\begin{array}{l}31.04 \\
(209)\end{array}$ \\
\hline & $\begin{array}{l}\text { NBDS } 3 \\
\text { R Rite }+5\end{array}$ & $\begin{array}{c}2.8 \times 10^{-5} \\
(\theta 8)^{-5}\end{array}$ & $\begin{array}{l}2.2 \\
(95)\end{array}$ & $\begin{array}{l}\text { B. } 0 \times 10^{-8} \\
(00)\end{array}$ & $\begin{array}{l}31.04 \\
3200)\end{array}$ \\
\hline $\begin{array}{l}3,6 \mathrm{~km} \\
\text { (Htll } 3)\end{array}$ & SSO 2 NO ND & $\begin{array}{l}\text { s. } 0 x^{1} 10^{-5} \\
\therefore(147)^{-5}\end{array}$ & $\begin{array}{l}2.87 \\
\left(234_{8}\right)\end{array}$ & $\begin{array}{l}0.1 \times 10^{-8} \\
{[151}\end{array}$ & $\begin{array}{l}36 \\
\left(271_{8}\right)\end{array}$ \\
\hline
\end{tabular}

\begin{tabular}{|c|c|}
\hline \multicolumn{2}{|c|}{$\operatorname{Max} 2$} \\
\hline Ampl & ILme \\
\hline $\begin{array}{l}4.0 \times 10^{-3} \\
\left(131^{-3}\right)\end{array}$ & $\begin{array}{l}393 \\
(91)\end{array}$ \\
\hline $\begin{array}{l}4.5 \times 10^{-4} \\
\left(19 z_{0}\right)^{-4}\end{array}$ & $\begin{array}{l}280 \\
(98)\end{array}$ \\
\hline $\begin{array}{c}2.6 \times 10^{-5} \\
\left(15 \theta_{0}\right)\end{array}$ & $\begin{array}{l}250 \\
\text { (88) }\end{array}$ \\
\hline $\begin{array}{l}1.2 \times 10^{-3} \\
(163)\end{array}$ & $\left(320_{B}\right)$ \\
\hline $\begin{array}{c}1.2 \times 10^{-5} \\
(30)\end{array}$ & $\begin{array}{l}263.8 \\
63111 / 2\end{array}$ \\
\hline$\underset{(\theta 9)}{2.8 \times 10^{-5}}$ & $\begin{array}{l}278.7 \\
13102 / 2\end{array}$ \\
\hline $\begin{array}{l}6.0 \times 10^{-5} \\
(1615)\end{array}$ & $\begin{array}{l}298 \\
1320 \mathrm{~g})\end{array}$ \\
\hline
\end{tabular}

Vielbllity a: $1 \mathrm{~km}$ (HIli $1 \mathrm{k}$ is $\mathrm{km} 10.1 \mathrm{~W}$

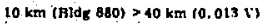

Ampl ln $w / \mathrm{cm}^{2}$ - aillcon

Time un ma

NBDS I we not filted 


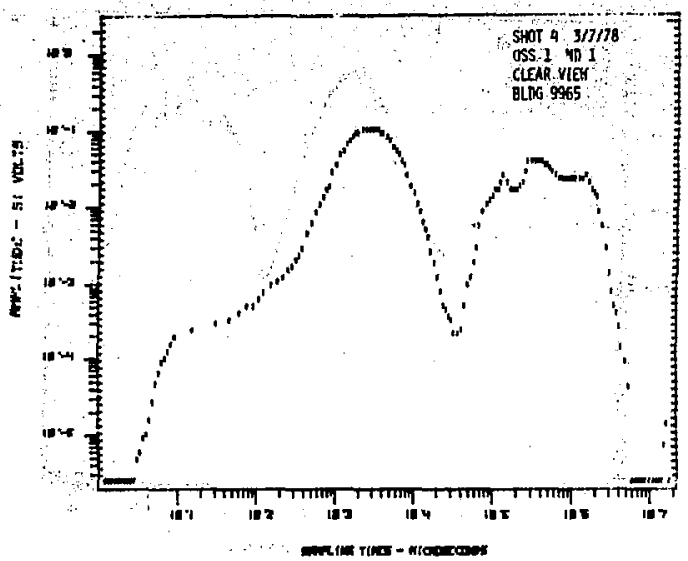

(a)

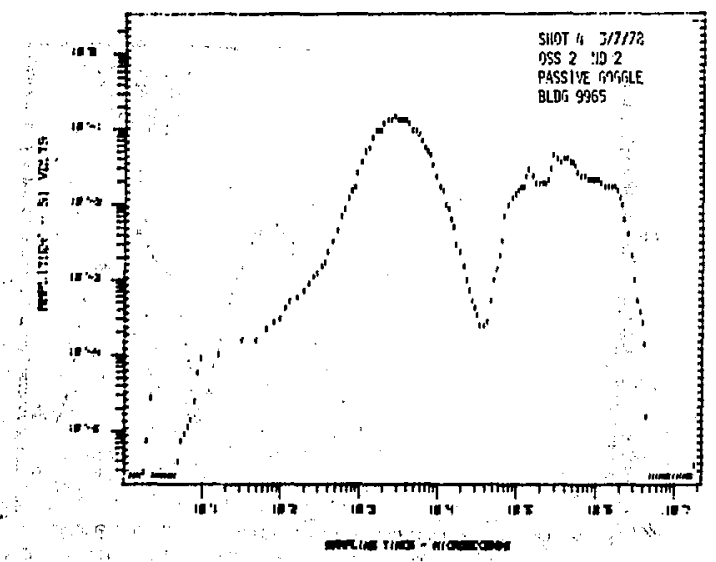

(b)

Figne 14: shot 4 


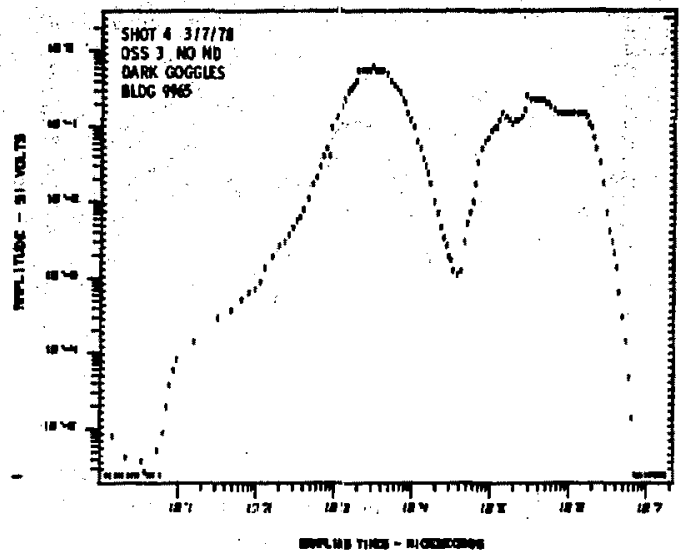

(c)

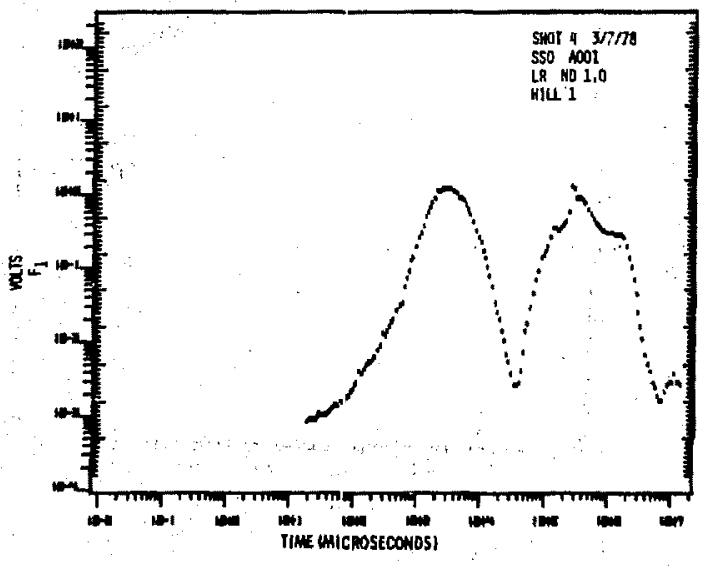

(d)

Figure 14, (cont) 


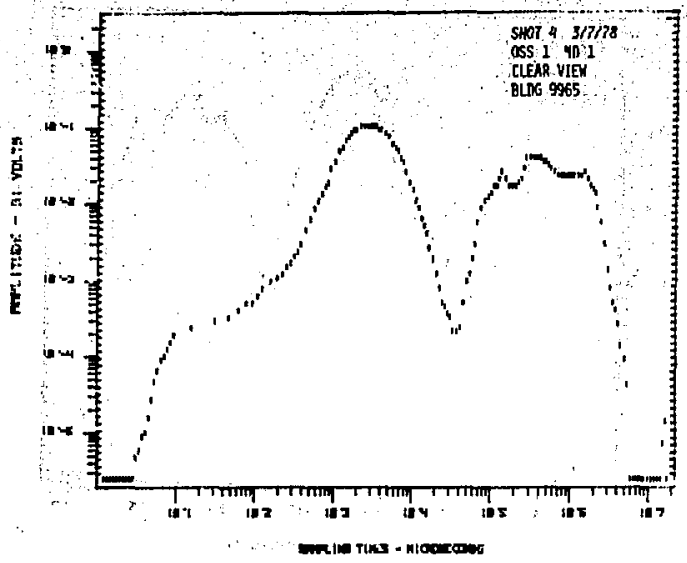

(a)

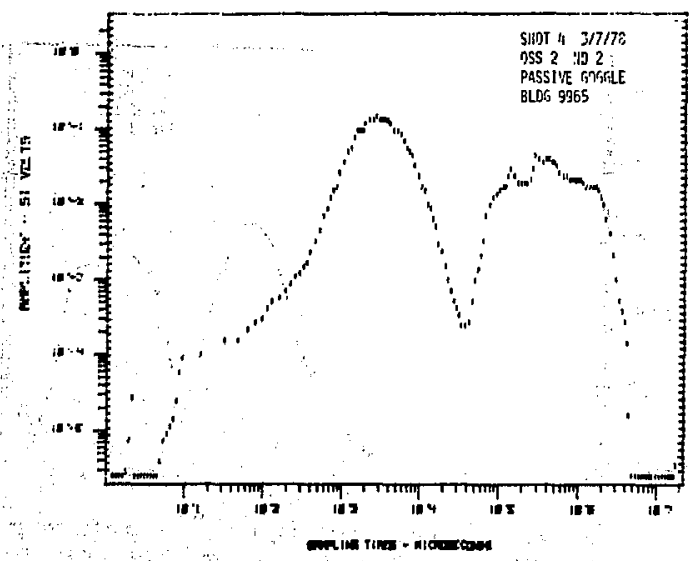

(b)

Figure 14. Shot 4 


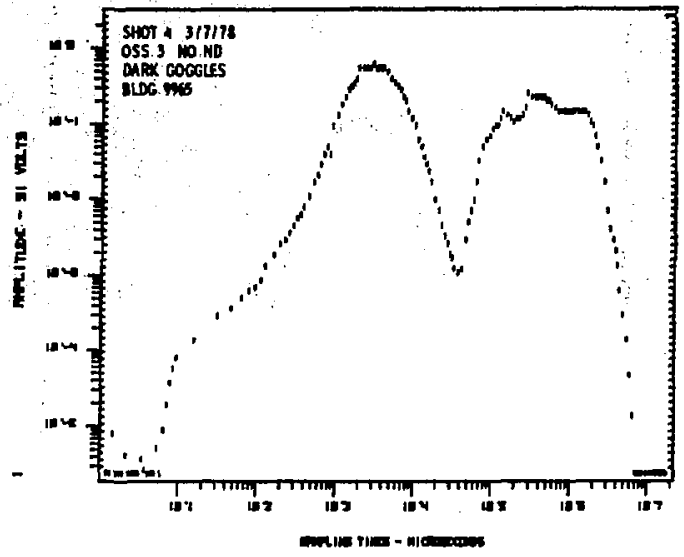

(c)

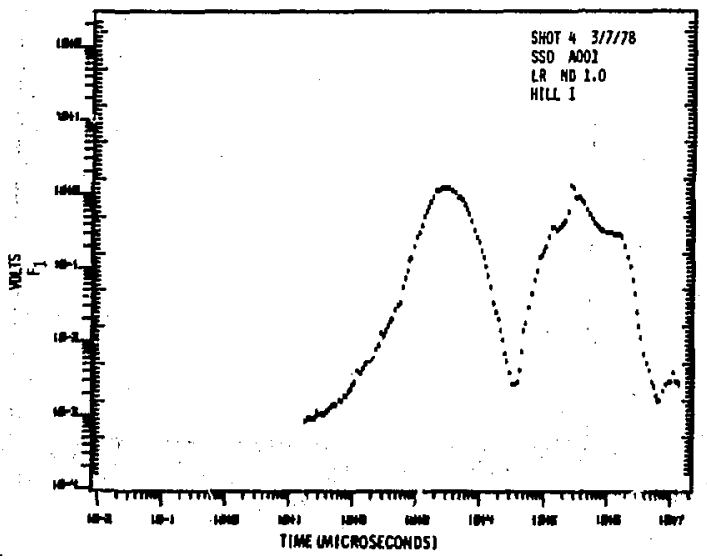

(d)

Figure 14, (cont) 


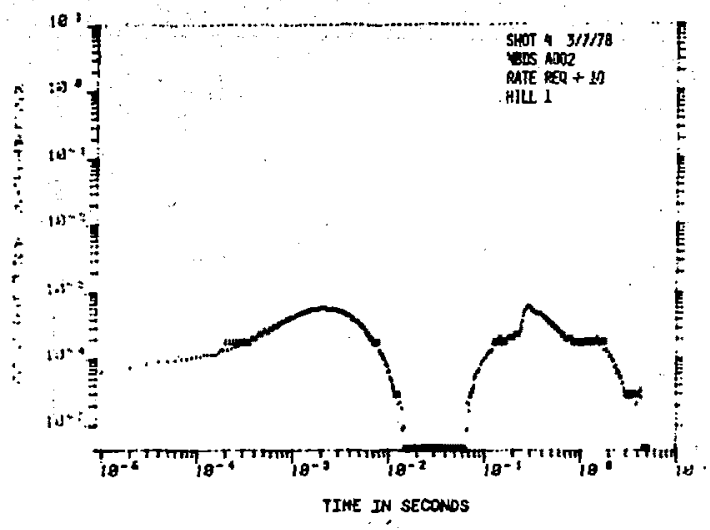

(e)

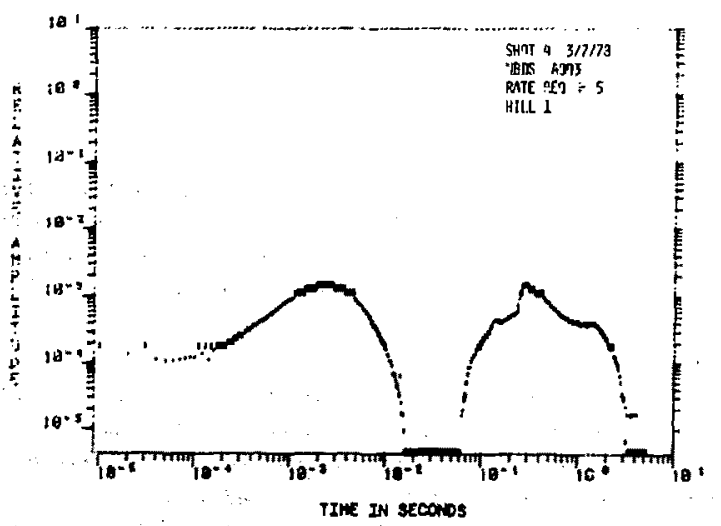

(1)

Fipure 14, (cont) 


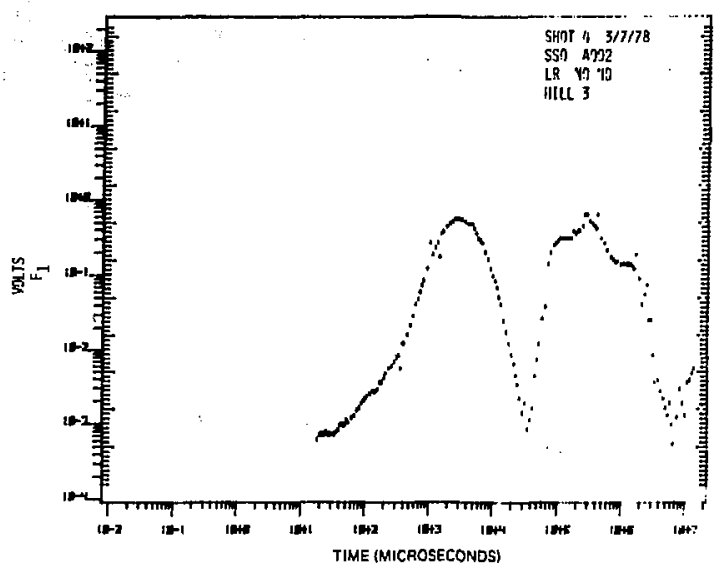

(g)

Figure 14, (concluded)

\section{Conclusiong}

Varlous concluelone concerning optical transmistion, tho ELS, and the detectoru are detalled in the following paragraphs. Overall, the ELS proved to be a gafe, usable, low-cost device for optical meanuremente. It has a hlgh potentlal value for tr-ining troops and for demonatrating -imulated optical and thermal nuclear effects without radiation or blast.

\section{Opticel Tranemision}

Figure is is a plot of Irradlance at first maximum as a factor of range for the 13 measuremente uaing the direct fline-of-alght) detectore. The data and the transmission loss curves have been rormalized at $1 \mathrm{~km}$ to adjust for any variation in mource output. The date points indicate a $1 / \mathrm{R}^{2}$ dependence within a factor of two. Improvement in net ingificant enough to juetify the more complex Monte Carlo acattering model. This plot is tor clear air (65-km visibility) to $n$ range of $10.5 \mathrm{~km}$. Treating the ELS a a point source, $4 \pi \mathrm{R}^{2}$ radiator, appears juotified under these condition. 


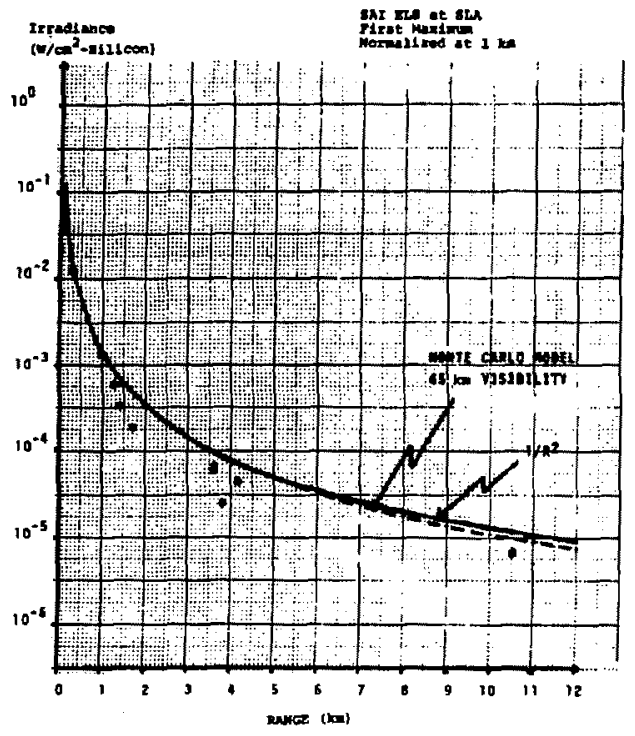

Figure 15. Plot of Irradlance at Firat Maximum

\section{Direct ve Scattered Ratio and Shape}

Table VII Let dat from Shot 4 at $1 \mathrm{~km}$. Comparing the SSO direct line-of-aight measurement (Fipure 14d) with the NaDS mattered-light measurements (Flgures 14e and 140 indicatea an excellent wavenhepe match and a direct/acattered ratio of 48 to 100 for the conditions. The cause of apread in the ratio has not been determined and is especlally surprising when she diflerent requirementy of the relaxed rate of riet trigger for the NeDS watlong are conaldered. Posable differences in leveling or in senuitlvity to direct component light in the tail of the lield-of-view rang be the caune. In any case, an eatimite for the short-range, clesr-air direct and scattered ratis ha been achloved and prewervation of acattured 11 ght waveshape bag been demonatrated. 


\section{TABLE VII}

Direct Scattered Fatlo

Shot 4 at $1 \mathrm{~km}$

Dlreet

SS 1 ND 1

1.2E-3 W/cm ${ }^{2}-$ silleon

Scattered*

NBDS 2

1.2E-5 W/ $/ \mathrm{cm}^{2}-$ sulicon

Rate +10

Scattered*

NBDS 1

. Rate $\div 5$

2. 8E-5 W/cm $\mathrm{cm}^{2}-$ slilcon

Direct/Scattered Ratlo 45 to 100 Clear Alr $1 \mathrm{~km}$

*May lnclude $\leq 1 \%$ d!rect component

\section{Nuclear Optical Simulator}

The Nuclear Burst Detection System (NBDS) was triggered on two ELS shot. A sensor station equipped with full optical diecriminants. $1 \mathrm{~km}$ from Shot 1. automatically processed the ELS gignature and reported a 274-kt nonfallout (NFO) producing buclear event. Unfortunately, failure of the communication link resulted in lass of the time history record from this aensor. On Shot 4, at $1 \mathrm{~km}$, two NBDS statione uBing epecial nondiscriminant eoftware and relaxed optical rateof-ribe requirements recorded the ELS time histury. When the optical waveshape discriminants which NBDS uses to define a nuclear event (Tahle VMI) were applied manually, they indicated that this ELS would have been reported as a 68.5 -kt fallout (FO) producing nuclear burst. Other NBDS measurements were attempted but falled because of inadequate ELS rate-of-rise at the given ranges (Bee next paragraph). Below is a summary of resulta garnered from applying the NBDS software discriminants to the measured ELS Aignatures, demongtrat Ing that an ELS of this type can meet present NBDS optical discr Im Inants and can be used to simulate nuclear optical effects:

- Shot 1 - An NBDS gensor station equlpped with a full set of optical diecr iminants (hardw/re and microprocesaor), hut without EMP requirements, automatically reported a $274-k t$ NFO event.

- Shot 2 - Manually applying microprocessor diecriminants to the recorded time history of line-of-aight detectora (OSS) Indtcated that a 246-kt NFO event would have been reported. $\because$ in

- Shel 3 - Manually applying dlacriminarits to the recorded time hintory of direct detector (OSS) indicated fillure to pans dis criminant No 5 because of irregular secund pulse.

\footnotetext{
*All NBDS senwor atation had Electromagnetic Pulse (EMP) requ(rements disabled.
} 
- Shot 4 - This chot triggered the NBDS aenuor etation with

relpred rate of-rige opticel requirements and daabled

EMP requlrementa. Manunlly applying m leroproceasor

discriminante to the recorded time hietory of the NBDS

Indteated that a $68.5-k t$ FO event would have been reported.

\section{TABLE VII}

NBDS

Microproceseor Diecriminanta

1. Flrat Sample $>6.3 \times 10^{-7} \mathrm{~W} / \mathrm{cm}^{2}$ (LD 32)

2. First Peak Tlme $<3,6 \mathrm{~ms}$ (Sample 113)

3. Time of (Flret Peak Ampltude +6.25 ) $>0.5 \mathrm{mg}$ \{Sample 41 \}

4. $5 \times$ Firot Peak Time $<$ Misimum Time $<70 \times$ First Peak Time

5. $4 \times$ Minlmum Time < Second Peak Time $<20 \times$ Minimum Time

6. Minimum Time $<180$ ma (Sample 285 )

7. Minlmum Width $<8 \times$ Minimum Time (< 96 Samples at $\mathrm{Sa} u$ e Leyei Detector (LD) Before $102 \mathrm{~ms}$ (Sample 264)!

8. At Leant One Third of Samples (08) Before $100 \mathrm{mg}$ (Sample 264 ) $>$ (First Peak Amplitude $\$ 6.25$ )

9. Single Peak Pulsea are Rejected (Second Peak Start Before L600 ms (Sampte 396)

10. Flat Firat Peak Pulgeg of Long Duration are Rejected (First Peak Amplitude > Avg Amplitude of Up to 126 Samples)

11. (Second Peak Amplltude $\div$ 6.25) > Amplitude of Minimum

12. All Sampleg Between Second Peak and 10 Samples Past Second Peak > (Second Peak Amplitude 4 Approximately 6. 25/3

(1.36 to 2.64) (Peaks Level Detector (LD-101)

\section{FIrtt Pulie Ratt of Rise}

To reduce falne triggering, bhangmeters dealgned to detect nuclear bursts use ac-coupled trigger circultry conaintent with nuclear optical rise times. Becauge of this requirement, the characterinte that most llmited the range at which the ELS could be detected was the rate-of-rlse of the fIrst pulse. Table $X$ presente the ELS rate of rine determined by two methods: the average rate, determined trom the firat peak amplitude/time ratlo, and the Initial rate from the presamples of Old style sultenate meneurementa. Comparing the mothoda indicates that the Initial rate of rine it alower by actor of 10 to 100 . than the average rate. This ia particularly troubleaome because backJround compenation eircuitry in the bhangmeter wlll compenmate out the stgnel untll it exceeds the triger rato-af-rice requirement, thus renultugg in late triggering and reduced amplitude. Comparing the meserurad. ribe times with the trituer raquiremente lifted in Tuble $\mathrm{DX}$ condirms the in ablity to trifger the NBDS beyond $1 \mathrm{~km}$ or direct bhengmeter beyond $10,6 \mathrm{~km}$. This is further verifled by the fact that the rource wes strong enough to be reen and recorded on movle fllm at over $28 \mathrm{~km}$. 
TABLE IX

Flrat Pulse Rate of Rive

Measurements:

\begin{tabular}{|c|c|c|}
\hline Method & $\begin{array}{l}\text { Rate of Rine } \\
10 \mathrm{~km} \text { to } 300 \mathrm{~m} \\
\left(W / \mathrm{cm}^{2}-1\right)\end{array}$ & $\begin{array}{l}\text { Rate of Rise } \\
\text { Souree } \\
\text { (W/a) } \\
\end{array}$ \\
\hline $\begin{array}{l}\text { Peak Amplitude Time } \\
\text { (Ayerage Rate) }\end{array}$ & $3,3 E-3$ to 3.8 & 1. $2 \mathrm{E} 10$ to $6.7 \mathrm{E} 10$ \\
\hline $\begin{array}{l}\text { OSS Presamples } \\
\text { (Initlal Rate) }\end{array}$ & 3. $1 \mathrm{E}-4$ to $8 \mathrm{E}-2$ & 1. $2 \mathrm{E} 8$ to $9.6 \mathrm{E} 9$ \\
\hline
\end{tabular}

Requlrements:

\begin{tabular}{|c|c|c|c|c|}
\hline & \multicolumn{2}{|c|}{$\begin{array}{l}\text { Rate of Riae } \\
\text { at Detector } \\
\text { (W/cm } 2-5)\end{array}$} & \multicolumn{2}{|c|}{$\begin{array}{c}\text { Rate of Rlbe } \\
\text { Source } \\
(\mathrm{W} / \mathrm{a})\end{array}$} \\
\hline & Direct & NBDS & Dlrect & NEDS \\
\hline $10 \mathrm{~km}$ Trigger & 3. $1 \mathrm{E}+4$ & $1,3 \mathrm{E}-2$ & $3.9 \mathrm{E \theta}$ & $3,2 E 12^{*}$ \\
\hline $1 \mathrm{~km}$ Trlgger & 3. $1 E-4$ & 1. $3 \mathrm{E}-2$ & 3. $9 \mathrm{ET}$ & $1.6 \mathrm{E} 11^{*}$ \\
\hline
\end{tabular}

Conclusion:

ELS a Detonated at SLA Hes Slow RIro Compared to Bhangmeter Requirementa

Which are Denigned to Detect Nuclear Burnts

Assumea direct scattered factor of 20 at $10 \mathrm{~km}, 100$ at $1 \mathrm{~km}$.

\section{Second Pulse Shape}

There was considerable variation in the shape of the second pulses. The flrat ahot went approximately as predicted from single bag testa. The second and fourth shota prodpced lower amplitude than expected and thowed irregularly ahaped maximume becaute of improper ignition on all or some of the eight bags. Late ignition was confirmed from high-apeed (1500 ft/a) movies of the events. Shot 3 renulted in a low, two-peaked shape cauned by aluminum powder made of a mixture of particles of two different sizes which burned at difforent rates. Comparing the amoothneas and connimtency of the 64-point first pulses to the 8-bag second pulsen indicatei that there if an advantage to using multipoint sources becaue a malfunction of a part which is a emall percentage of the whole would not greatly affect the renulto.

\section{Source Symmetry}

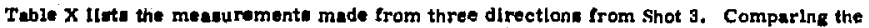
entimated source etrongth (calculated by folding back using $9 \pi{ }^{2}$ ) Indicates, to within a factor of two, that both first and aecond pules unite are nondirectional. Also, there is only regligible tranemiselon lose of output of the flrat pules through the bage of the mecond pulue, 
Shat 3 (3/9/78)

\begin{tabular}{|c|c|c|c|c|c|c|}
\hline \multirow[b]{2}{*}{$\begin{array}{l}\text { Pang: } \\
\text { (lum) }\end{array}$} & \multirow[b]{2}{*}{$\begin{array}{l}\text { Uirection } \\
\text { (Afprox) }\end{array}$} & \multirow[b]{2}{*}{ Ingrument } & \multicolumn{2}{|c|}{ Max 1} & \multicolumn{2}{|c|}{$M a n$} \\
\hline & & & $\begin{array}{c}\text { Shpu } \\
\text { (W/ } / \mathrm{cm}^{2}-\text { Sillican) }\end{array}$ & $\begin{array}{l}\text { soures serenfin } \\
\text { (W-selleon) }\end{array}$ & 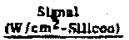 & $\begin{array}{l}\text { Soures surengh } \\
\text { (W-silleon) }\end{array}$ \\
\hline mim is & Nerth & OSS I NOND & 9. 7E-4 & $1.22 E B$ & $3.2 E-4$ & 4. 0::7 \\
\hline $\begin{array}{c}1.26 \\
\text { (Deck Stde) }\end{array}$ & South & ${ }_{n}^{5 S O} 2$ ND 1 & C. $5 E+4$ & Q. ม8E? & $2, D E-1$ & 5. BET \\
\hline (Soler Tnuter) & Eert & $\operatorname{SSO}$ INIJ 1 & $2.0 E-4$ & 6. 1E7 & $1.3 \mathrm{E}=4$ & $4.2 \mathrm{E} 7$ \\
\hline
\end{tabular}

Output and Yleld Scaling.

Table XI latte the optical source strengthe of the four ELS ahots. The firat-pulge untts averaced 1. $388 \mathrm{~W}$-glutcon and the Shot 1 second-pulse unlt achieved $2.188 \mathrm{~W}$-slllcon (see above concernlag Shote 2. 9, and 4 second pulse). For comparlson, the table also ligts source strengths of varlout other events. Consldering the small quantity of explos l ve (approximately $150 \mathrm{~g}$ ) and the low cost of an ELS, the optical output advantages are considerable.

\section{TABLE XI}

\section{ELS Output}

$\begin{array}{ccc}\text { Shot No } & \begin{array}{c}\text { Firgt Pulse } \\ \text { (64 Points) }\end{array} & \begin{array}{c}\text { Second Puige } \\ (8 \text { Bagg) }\end{array} \\ 1 & 1.6 E 8 & 2.1 E 8 \\ 2 & 8.7 E 7 & 1.2 E 7 \\ 3 & 1.2 E 8 & 4.0 E 7 \\ 4 & 1.5 E 8 & 1.5 E 8\end{array}$

Source Strengh in w-Sulcon Calculated From Meagurement at $1 \mathrm{~km}$.

\begin{tabular}{|c|c|c|}
\hline & Other Sources" & \\
\hline Nuclear Burat & Second Maximum (1 kt) & 1. $8 \mathrm{E} 13$ \\
\hline Diee Throw & 630 TOna ANFO & 1.21210 \\
\hline Predice Throw II & 120 TOna ANFO & 7. 11:9 \\
\hline Lightn lng & Return Strokes & $1 E B$ 10 $1 F 12$ \\
\hline
\end{tabular}

Fource Strengtha in W-Sillcon 


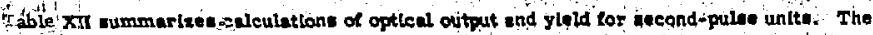

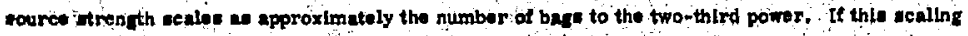

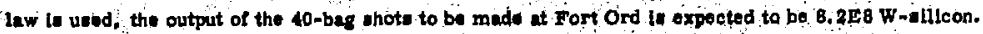

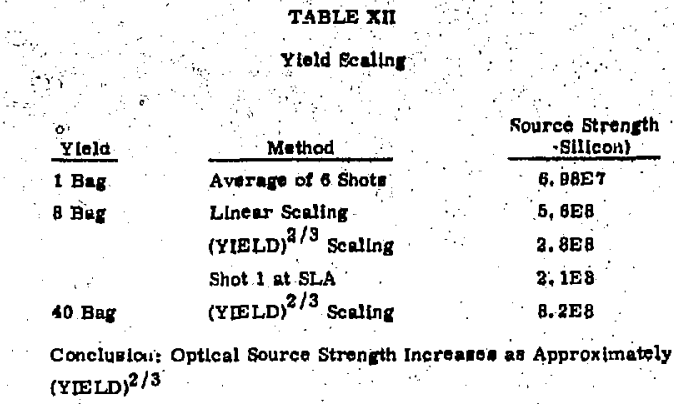

Reforences.

1. Development of a Large Scale Thermal Ridiation Simulator, SAl-77-528-sV (Final Report; Sunhyvale: Science Applications Inc, 30 November I8VT);

2. R. G. Bradiey et al, Super Suftcase Optlcal: Operations Manual, Vol, 1 (Albuquerque: Sandia Laboratories, 1 1675\%. 


\section{AF'PENDIX}

Data A vallable From and Particlpants In ELS Shot: Conducted at Sendla Laboratorles 
Data Available From

SAI ELS/Thermal Tests at SLA

\begin{tabular}{|c|c|c|c|c|}
\hline Data Type & Organization & Shot(s) & Range(s) & Description \\
\hline $\begin{array}{l}\text { Calorimeter } \\
\text { (Q vs Time) }\end{array}$ & $\begin{array}{c}\text { NWEF } \\
\text { (Pete Hughes) }\end{array}$ & $1,2,3,4$ & $\begin{array}{l}3.5 \mathrm{~m}, 4.5 \mathrm{~m}, 5.5 \mathrm{~m} \\
\text { south of }{ }^{11} \mathrm{C}^{11} \text { syg. }\end{array}$ & $\begin{array}{l}\text { 3000-Hz Circular Foil } \\
\text { Heat Flux Gages }\end{array}$ \\
\hline $\begin{array}{l}\text { Source Strength } \\
\text { (Thermal) }\end{array}$ & $\begin{array}{c}\text { SLA-9337 } \\
\text { (Ned Keltner) }\end{array}$ & $1,2,3,4$ & $\begin{array}{l}4.0 \mathrm{~m} \\
\text { south of "C" ays. }\end{array}$ & $\begin{array}{l}2 \text { Circular-Foil Gages } \\
1 \text { Silicon-Diode Sensor }\end{array}$ \\
\hline $\begin{array}{l}\text { Optical Signal } \\
\text { (Suns vs Time) }\end{array}$ & $\begin{array}{c}\text { SAI } \\
\text { (Jerry Lattery) }\end{array}$ & $1,2,3,4$ & $\begin{array}{l}200 \mathrm{ft} \\
\text { north of "C" sys. }\end{array}$ & $\begin{array}{l}\text { Photodiode } \\
\text { Oscilloscope }\end{array}$ \\
\hline Optical Signal & $\begin{array}{c}\text { SLA }-9412 \\
\text { (Jale Fastle) }\end{array}$ & 2,3 & $\sim 300 \mathrm{~m}$ north & Diode \\
\hline $\begin{array}{l}\text { Optical Signal } \\
\text { (W/ } / \mathrm{cm}^{2} \text { vs Time) }\end{array}$ & $\begin{array}{c}\text { SLA-1245 } \\
\text { (Ron Glaser) }\end{array}$ & $1,2,3,4$ & $\begin{array}{l}300 \mathrm{~m} \text { to } 10.5 \mathrm{~km} \\
\text { north, south, \& east }\end{array}$ & $\begin{array}{l}\text { Silicon Diode } \\
\text { Bhangmeters }\end{array}$ \\
\hline $\begin{array}{l}\text { Photometrics } \\
\text { (1500 } / \mathrm{s})\end{array}$ & $\begin{array}{l}\text { SLA-9412 } \\
\text { (Terry Leighley) }\end{array}$ & $\begin{array}{l}1 \\
2 \\
2 \\
2 \\
2 \\
3 \\
3 \\
3 \\
4 \\
4\end{array}$ & $\begin{array}{l}90 \mathrm{ft} \text { north of "C" } \\
\text { enst \& west } \\
5.5 \mathrm{~m} \text { south of "C" } \\
90 \mathrm{ft} \text { north of "C" } \\
\text { east \& west } \\
5.5 \mathrm{~m} \text { south of "C" } \\
90 \mathrm{ft} \text { north of "C" } \\
\text { cast \& west } \\
90 \mathrm{ft} \text { north of "C" } \\
\text { east \& west }\end{array}$ & $\begin{array}{l}\text { Passive Goggle } \\
\text { Materials (6 cameras) } \\
\text { Active \& Passive Goggle } \\
\text { Active \& Passive Goggle } \\
\text { Materials (6 camerag) } \\
\text { Active \& Passive Goggle } \\
\text { Active Goggle } \\
\text { Materials (6 cameras) } \\
\text { Passive Goggle } \\
\text { At Bags (2 camera 3) }\end{array}$ \\
\hline$(400-500[\mathrm{t} / \mathrm{s})$ & $\begin{array}{l}\text { Sl.t-9412 } \\
\text { (Terry Leighley) }\end{array}$ & $\begin{array}{l}3,4 \\
4\end{array}$ & $\begin{array}{l}\text { north, east, south } \\
\sim 300 \mathrm{~m} \text { north }\end{array}$ & $\begin{array}{l}\text { Overall Views } \\
\text { Active \& Pagsive Goggle }\end{array}$ \\
\hline \multirow[t]{3}{*}{$\begin{array}{l}\text { Documentary } \\
\text { (Motion Picture) }\end{array}$} & $\begin{array}{c}\text { SIA-3153 } \\
\text { (Gicne Noore) }\end{array}$ & $1,2,3,4$ & $\mathrm{GZ}$, and $1 \mathrm{~km}$ & All Aspects \\
\hline & $\begin{array}{l}\text { SLA-1245 } \\
\text { (1)ean Thornbrough) }\end{array}$ & $1,2,3,4$ & $1 \mathrm{~km}$ & $\begin{array}{l}\text { Shots, Visitors } \\
\text { Bhangmeter Setup }\end{array}$ \\
\hline & $\begin{array}{c}S \mathrm{~T} A-1245 \\
(F \text { red Bauer) }\end{array}$ & $1,2,3,4$ & $1.26 \mathrm{~km}$ to $25 \mathrm{~km}$ & $\begin{array}{l}\text { Bhangmeter Mounted } \\
\text { (2 locationg shot) }\end{array}$ \\
\hline
\end{tabular}


$\frac{\text { Date Type }}{\text { Documentary }}$ (Stille)

$$
\text { (Stinte) }
$$

Documentary.

(Sidaes).

Microbaragraph

Impact Noise

Nephelometer

\section{Vinibility}

(Weather)
Organization

SLA-9412

(Terry Leighley)

SLA-3162 (Russell Smith)

SAI

(John Dishon) (Wilson North)

NWEF

(Pete Hughes)

\section{SAI (SLA-1132)}

(Mike Melonnel)

SLA-3311

(BIII Stocum)

SAI (SLA-5713)

(Mlke Mcloonne1)

SLA-1245

(Ron Glaser)
Shot(t)

2,3

$1,2,3,4$

2

2,3

3,4

4

$1,2,3,4$

$1 \mathrm{~km}$ to $25 \mathrm{~km}$
Deecrtption

All aspect.

(33 color)

Shot Sequence

(14, B\&W)

All aspects

All aspects

Materials

( 80 before and gefter)

Overpressure vs Time

Peak presoure

Scattering Coet.

(with/vithout henteir)

VisLometer

Alrport weather 